OECD Economics Department Working Papers No. 613

Reforming Housing and Regional Policies

in Korea

\author{
Randall S. Jones, \\ Tadashi Yokoyama
}

https://dx.doi.org/10.1787/241645113684 
Organisation de Coopération et de Développement Économiques

Organisation for Economic Co-operation and Development

16-May-2008

ECONOMICS DEPARTMENT

English - Or. English

REFORMING HOUSING AND REGIONAL POLICIES IN KOREA

ECONOMICS DEPARTMENT WORKING PAPER No. 613

By Randall S. Jones and Tadashi Yokoyama

All OECD Economics Department Working Papers are available on the OECD Internet website at www.oecd.org/eco/working_papers

JT03245800

Document complet disponible sur OLIS dans son format d'origine

Complete document available on OLIS in its original format 


\section{ABSTRACT/RÉSUMÉ \\ Reforming housing and regional policies in Korea}

The government has introduced five policy packages since August 2005 to stabilise house prices, mainly due to concerns about possible spill-overs from the capital region to other parts of the country, even though the increase on a nation-wide basis has been modest compared to other OECD countries. The planned expansion in housing construction in the capital region will reduce upward pressure on house prices. However, other policies aimed at reducing "speculative" demand and lowering house prices, such as the price ceiling on new houses, are likely to constrain supply and result in stronger price pressures in the longer term. The government should shift its focus from short-term price fluctuations in house prices to creating an efficient housing market, relying more on private-sector supply. Concern about increasing concentration in the capital region should be dealt with through economic instruments to address externalities, such as pollution and congestion, while phasing out the restrictions on construction in the capital region.

This Working Paper relates to the 2007 OECD Economic Survey of Korea (www.oecd.org/eco/surveys/korea).

JEL classification: R11, R21, R31.

Keywords: Korea; housing policies; house prices; housing markets; real estate price bubbles; mortgage lending; property taxes; capital gains taxes; regional policy; air pollution; balanced regional development; innovation cities; enterprise cities; fiscal decentralisation.

\section{Réformer la politique du logement et la politique régionale en Corée}

Le gouvernement a mis en place depuis août 2005 cinq séries de mesures destinées à stabiliser les prix des logements, même si la hausse de l'immobilier a été modeste en Corée par rapport à d'autres pays de l'OCDE. Le développement prévu de la construction de logements dans la région de la capitale atténuera les pressions à la hausse sur les prix immobiliers. Mais d'autres mesures visant à réduire la demande «spéculative» et à faire baisser les prix des logements, notamment le plafonnement des prix des logements neufs, sont de nature à limiter l'offre et à accentuer les pressions sur les prix à long terme. Au lieu d'essayer avant tout de remédier aux fluctuations à court terme des prix immobiliers, le gouvernement devrait s'efforcer de créer un marché du logement qui soit efficient, tout en s'appuyant davantage sur l'offre privée. Face au problème de la concentration de plus en plus forte dans la région de la capitale, il faudrait utiliser des instruments économiques pour remédier aux externalités, en particulier la pollution et les encombrements, tout en mettant fin progressivement aux restrictions à la construction dans la région de la capitale.

Ce Document de travail se rapporte à l'Étude économique de l'OCDE de Corée, 2007 (www.oecd.org/eco/etudes/corée).

Classification JEL : R11, R21, R31.

Mots clés: Corée; politique du logement; prix immobiliers; marché du logement; bulles immobilières; crédit hypothécaire; impôts immobiliers; impôts sur les plus-values; politique régionale; pollution atmosphérique; villes innovantes; villes pour l'entreprise; décentralisation budgétaire

\section{Copyright OECD 2008}

Application for permission to reproduce or translate all, or part of, this material should be made to: Head of Publications Service, OECD, 2 rue André-Pascal, 75775 Paris Cedex 16, France. 


\section{TABLE OF CONTENTS}

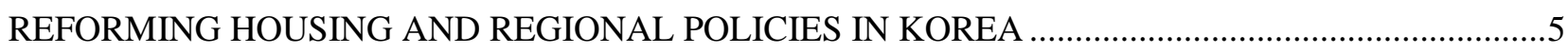

Is there a real estate price bubble in Korea? ..........................................................................................

While nation-wide house prices are stable, some areas have experienced larger increases ...................10

Volatility has been exacerbated by frequent policy changes and supply restrictions.............................11

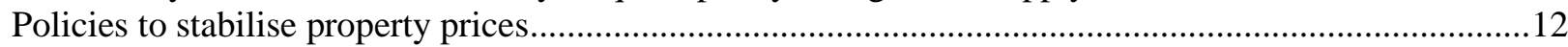

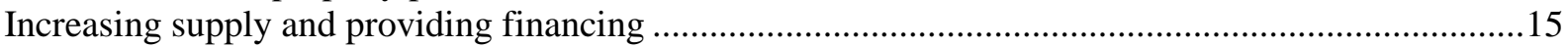

Policies to restrict demand: reducing bank lending and cracking down on "speculators"....................16

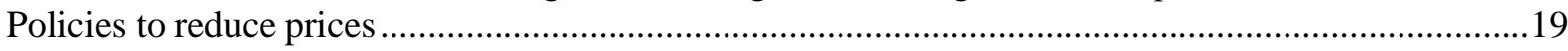

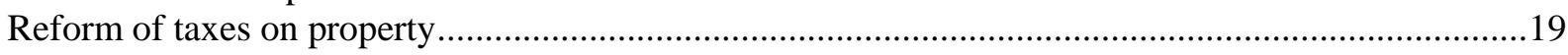

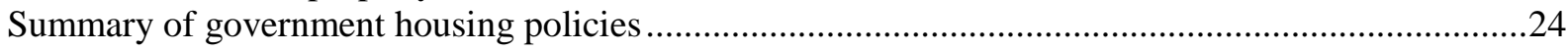

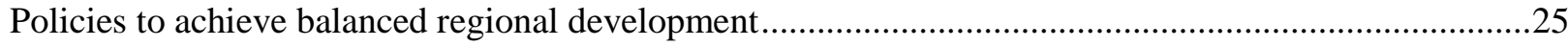

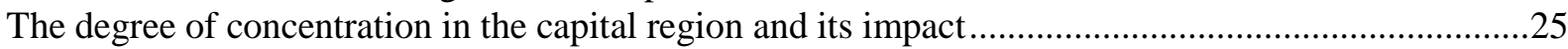

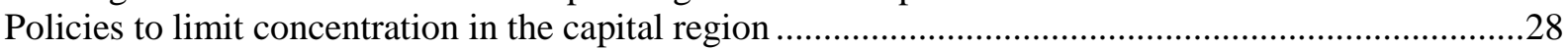

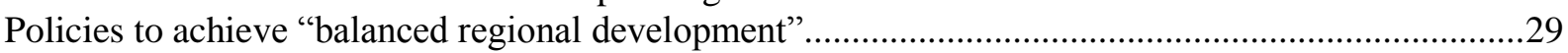

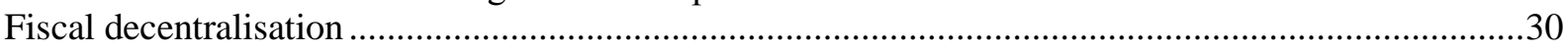

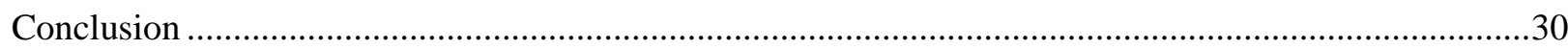

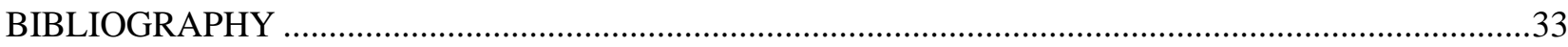

Annex 1 Key elements of the policy packages for property price stabilisation since 2005 .....................35

\section{Tables}

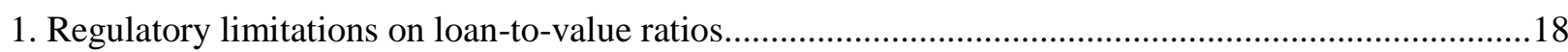

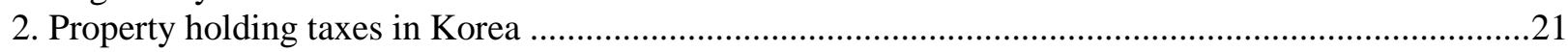

3. Recent changes in the capital gains tax on property in Korea .........................................................2

\section{Figures}

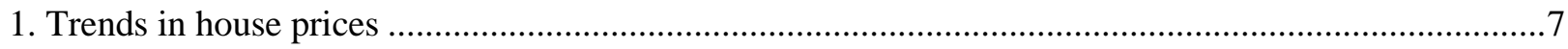

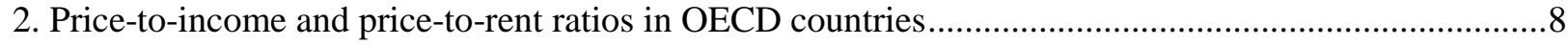

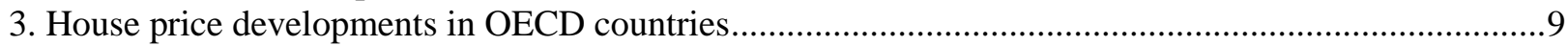

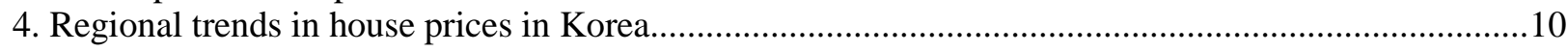

5. Correlation between real house prices and the business cycle.....................................................12

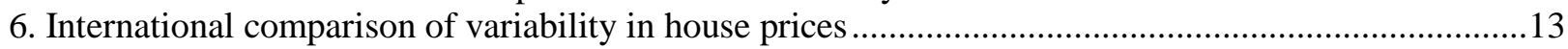

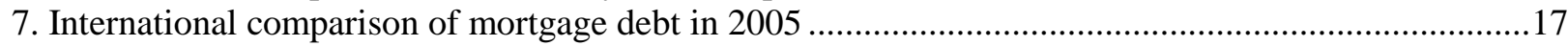

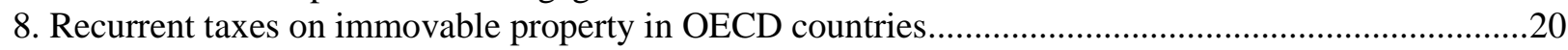

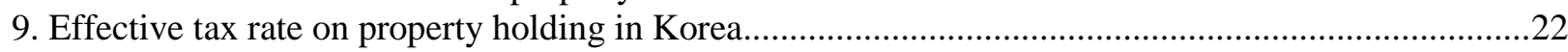

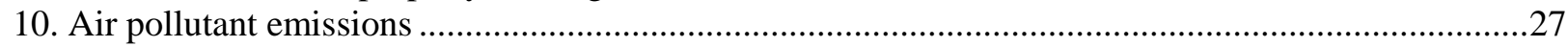


ECO/WKP(2008)21

\section{Boxes}

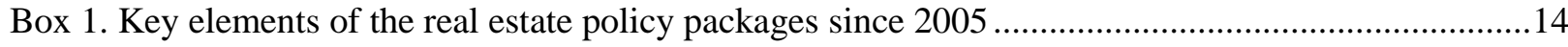

Box 2. Japan's experience with a real estate price bubble ...................................................................24

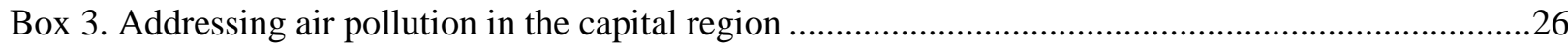

Box 4. Summary of recommendations for housing and regional policies in Korea .................................31 
ECO/WKP(2008)21

\title{
REFORMING HOUSING AND REGIONAL POLICIES IN KOREA
}

\author{
Randall S. Jones and Tadashi Yokoyama ${ }^{I}$
}

1. There is widespread concern about a possible real estate price "bubble" in Korea. ${ }^{2}$ The government is sensitive to increases in real estate prices in certain areas of Seoul, reflecting concern about possible spill-overs to other parts of the country and a deterioration in wealth distribution. The government has pledged at the highest political levels to stabilise real estate prices. On a nation-wide basis, however, the rise in real house prices in Korea has been moderate compared to other OECD countries. Korea has a long history of using interventionist policies to control short-term fluctuations in property prices. Real estate policies have been relaxed to stimulate construction activity during sluggish periods and tightened when prices increase (see the 2005 OECD Economic Survey of Korea). However, frequent policy changes have tended to exacerbate price volatility. ${ }^{3}$

2. The government has introduced five comprehensive real estate policy packages since August 2005. The packages have boosted the planned increase in housing supply in the capital region, with the government taking the leading role. Other new measures have aimed at reducing "speculative" demand, for example by changing the tax system and setting stricter ceilings on mortgage loans by financial institutions. Other policies aim at reducing house prices through price caps on new houses. The government measures have to be seen in the context of its objective to limit the large house price swings in the short term. Despite the merits of such a policy objective, some of these measures may reduce housing supply and increase price pressures in the longer term. In addition, supply is restricted by rules that limit the reconstruction of old apartments in areas where prices are rising the most rapidly. The average nationwide house price index, which increased at a $1 \%$ real annual rate during the first half of 2005 prior to the introduction of the first real estate policy package in August 2005, accelerated to 9\% in 2006.

1. Randall S. Jones is head of the Japan/Korea Desk in the Economics Department of the OECD and Tadashi Yokoyama was an economist on that desk. This paper is based largely on material from the $O E C D$ Economic Survey of Korea published in June 2007 under the authority of the Economic and Development Review Committee (EDRC). The authors would like to thank Andrew Dean, Val Koromzay, Willi Leibfritz and Taesik Yoon for valuable comments on earlier drafts. Special thanks go to Lutécia Daniel for technical assistance and to Nadine Dufour and Therese Walsh for technical preparation.

2. While the term "asset price bubble" is frequently used, it remains controversial, given disagreement about measurement and definition of a bubble. Nevertheless, there is agreement that many periods of financial instability and crises were associated with equity or real estate price boom-bust cycles (Helbling, 2005).

3. Government measures to calm the real estate market may suggest that the authorities expect strong price pressures ahead, encouraging households to quickly purchase real estate. 
3. Housing policies are also linked with the goal of balanced regional development, which the government expects would reduce housing demand in the capital region. This would, however, contradict the government's aim of developing that region as an international economic hub. The recent plans to boost housing supply in the capital region will accommodate the expected population increase of one million persons in the capital region by 2011, bringing the total to around 24 million, according to the government's long-term plan.

4. This paper examines the housing market and regional development policies. The first section analyses the recent development of property prices. The second section assesses the government policies aimed at stabilising property prices, followed by an evaluation of the government's regional policies. The paper concludes with a set of recommendations, shown in Box 4, to improve housing and regional policies in Korea.

\section{Is there a real estate price bubble in Korea?}

5. Over the past 20 years, Korea has experienced wide fluctuations in its real house prices, with sharp increases at the end of the 1980s (Figure 1). The government initiative to build 2 million housing units during the period 1989-92 resulted in an extended period of house price decline, exacerbated by the 1997 crisis. There have been two periods of rising prices since then -2001-2003 and again in 2006. Nevertheless, the nation-wide house price index in 2006 was 18\% lower in real terms than in 1986, making Korea one of only four OECD countries to experience real price declines over that period. In nominal terms, the nation-wide house price has increased at a 3.7\% annual rate over the past 20 years, one percentage point below the $4.7 \%$ inflation rate, as measured by the consumer price index. Other measures commonly used to assess housing market conditions, such as the price-to-income ratio and the price-to-rent ratio, also indicate that house prices in Korea have not risen very much over the past decade compared to other OECD countries (Figure 2). 
Figure 1. Trends in house prices

House purchase price composite index in real terms ${ }^{1}$

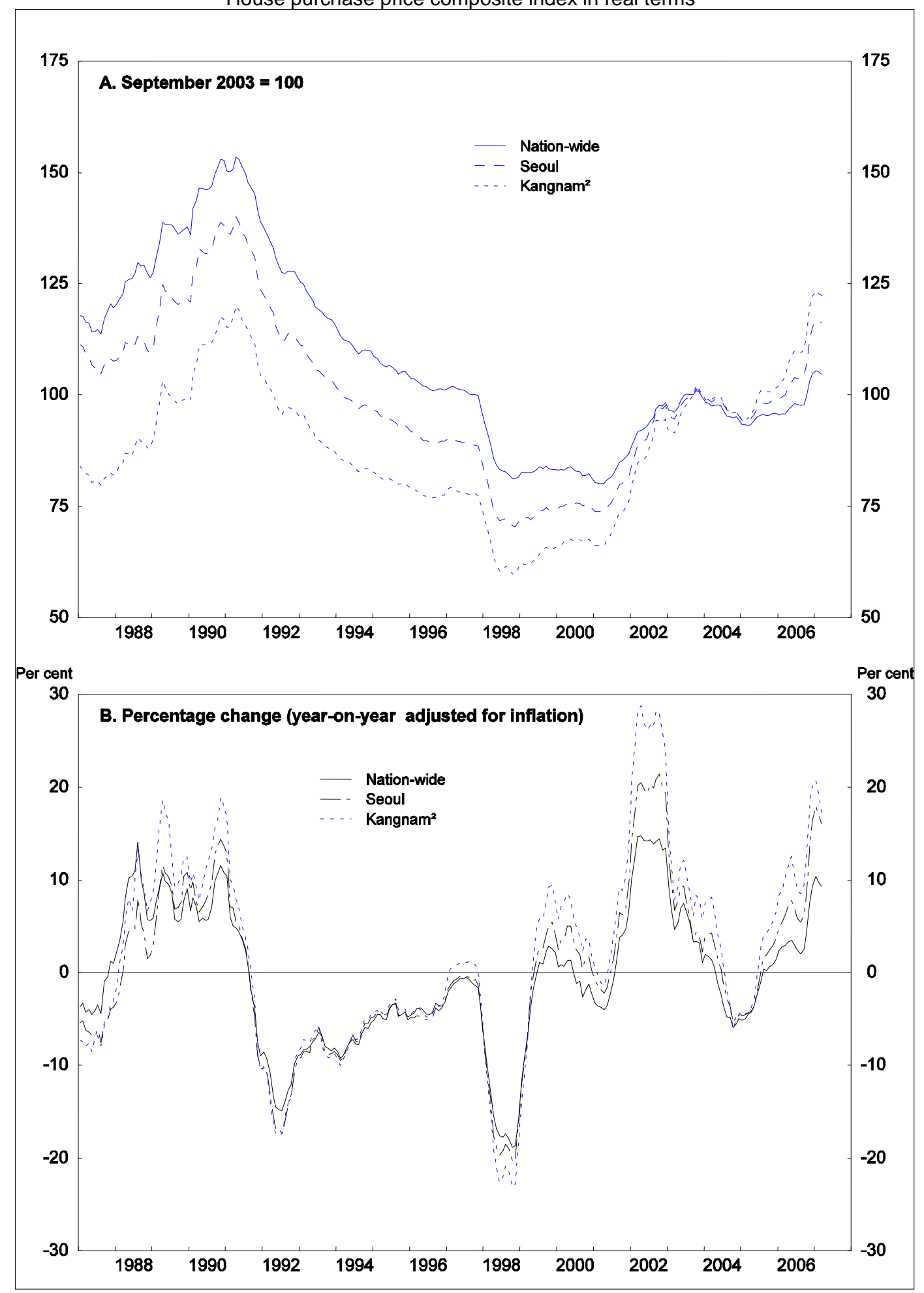

1. Includes single-family houses and apartments. The index is deflated by the overall consumer price index. 2. An area of Seoul.

Source: Kookmin Bank, National Housing Price Survey. 
Figure 2. Price-to-income and price-to-rent ratios in OECD countries

Sample average $=100$

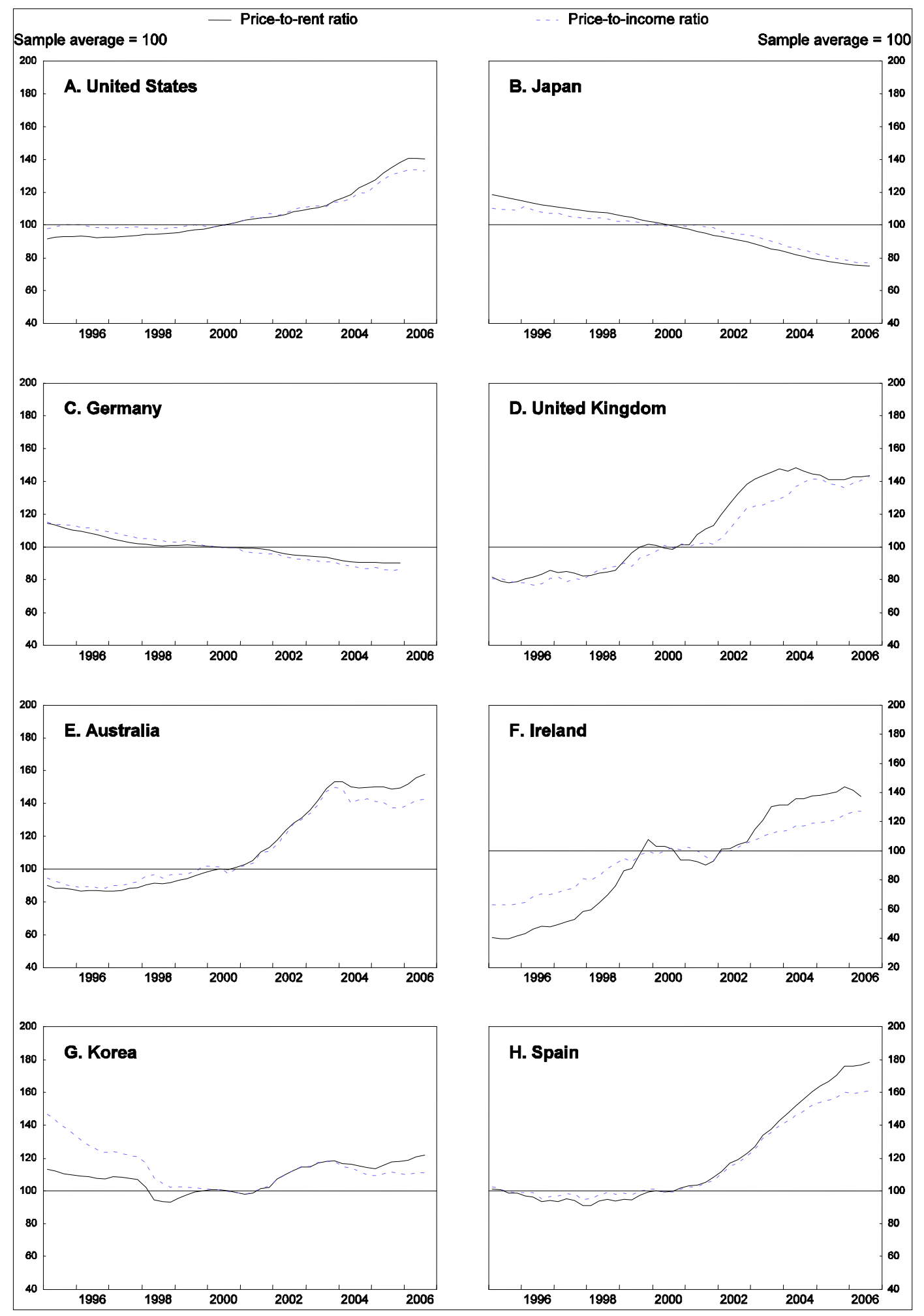

Source: Girouard, N., M. Kennedy, P. van den Noord and C. Andre (2006), "Recent house price developments: the role of fundamentals", Economics Department Working Paper No. 475, OECD, Paris. 
6. Moreover, recent increases in house prices have been relatively small compared to other OECD countries. A number of OECD countries have experienced a housing boom since 2000. The rise in real house prices since 2000 is $42 \%$ on average in the OECD area, almost double the increase in Korea (Figure 3). ${ }^{4}$ After declining in 2004, nation-wide real house prices rose at a 5\% annual rate in 2005-06 in Korea. However, steep increases in apartment prices in some areas of Seoul had spread to other parts of the capital region by the end of 2006.

\section{Figure 3. House price developments in OECD countries}

Percentage change in real terms between 2000 and the latest quarter available ${ }^{1}$

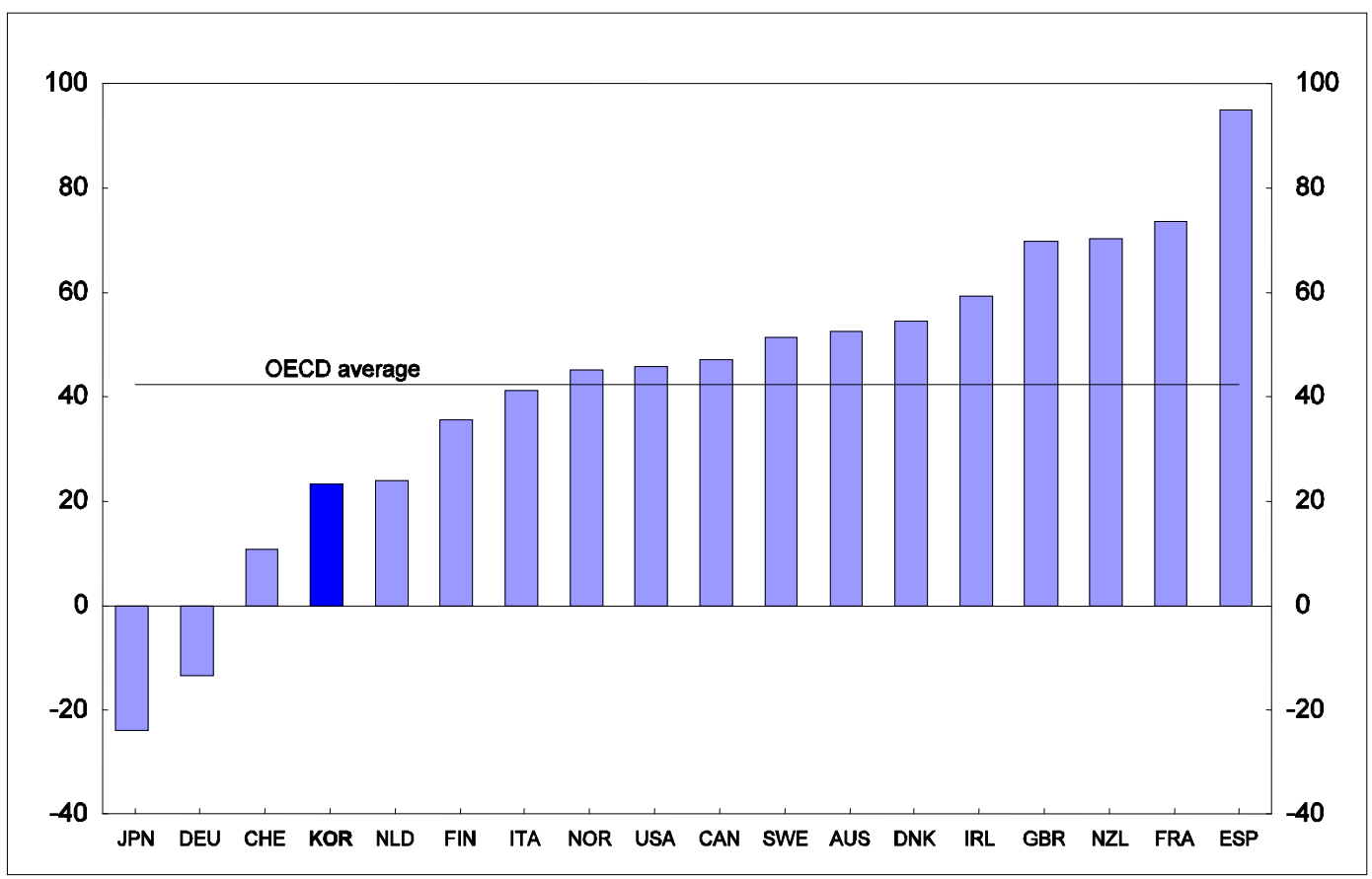

1. Nominal house price deflated by the overall consumer price index. Data for Korea includes the fourth quarter of 2006.

Source: Girouard, N., M. Kennedy, P. van den Noord and C. Andre (2006), "Recent house price developments: the role of fundamentals", Economics Department Working Paper No. 475, OECD, Paris.

4. A number of factors have contributed to the recent rise in property prices: i) the worldwide decline in interest rates; ii) the development of mortgage markets through deregulation; iii) the rise in the proportion of owner-occupied houses; iv) demographic factors, including immigration; v) supply bottlenecks due to various regulations; and vi) increases in per capita income. The degree of contribution by each factor differs considerably across countries (Girouard et al., 2006). The development of financial markets has reduced risk premia, resulting in higher purchase prices. A number of studies indicate that the rise in property prices has stimulated private consumption through wealth effects in countries that have large, efficient and responsive mortgage markets (Catte et al., 2004). 


\section{While nation-wide house prices are stable, some areas have experienced larger increases}

7. The concern over a possible real estate bubble stems from rising prices in a geographically limited area in the southern part of Seoul, known as Kangnam, and some suburban cities (Figure 4). ${ }^{5}$ After declining 5\% in 2004 in real terms, the average house price in Kangnam began rising in 2005. By the time of the first real estate package in August, it was up 4\% (year-on-year) in real terms and the pace accelerated to $20 \%$ by the end of 2006 . House price increases in Kangnam have been relatively strong over the past few decades. Indeed, they have risen $26 \%$ in real terms since 1986 compared to a $9 \%$ fall in Seoul and an $18 \%$ decline nation-wide.

Figure 4. Regional trends in house prices in Korea

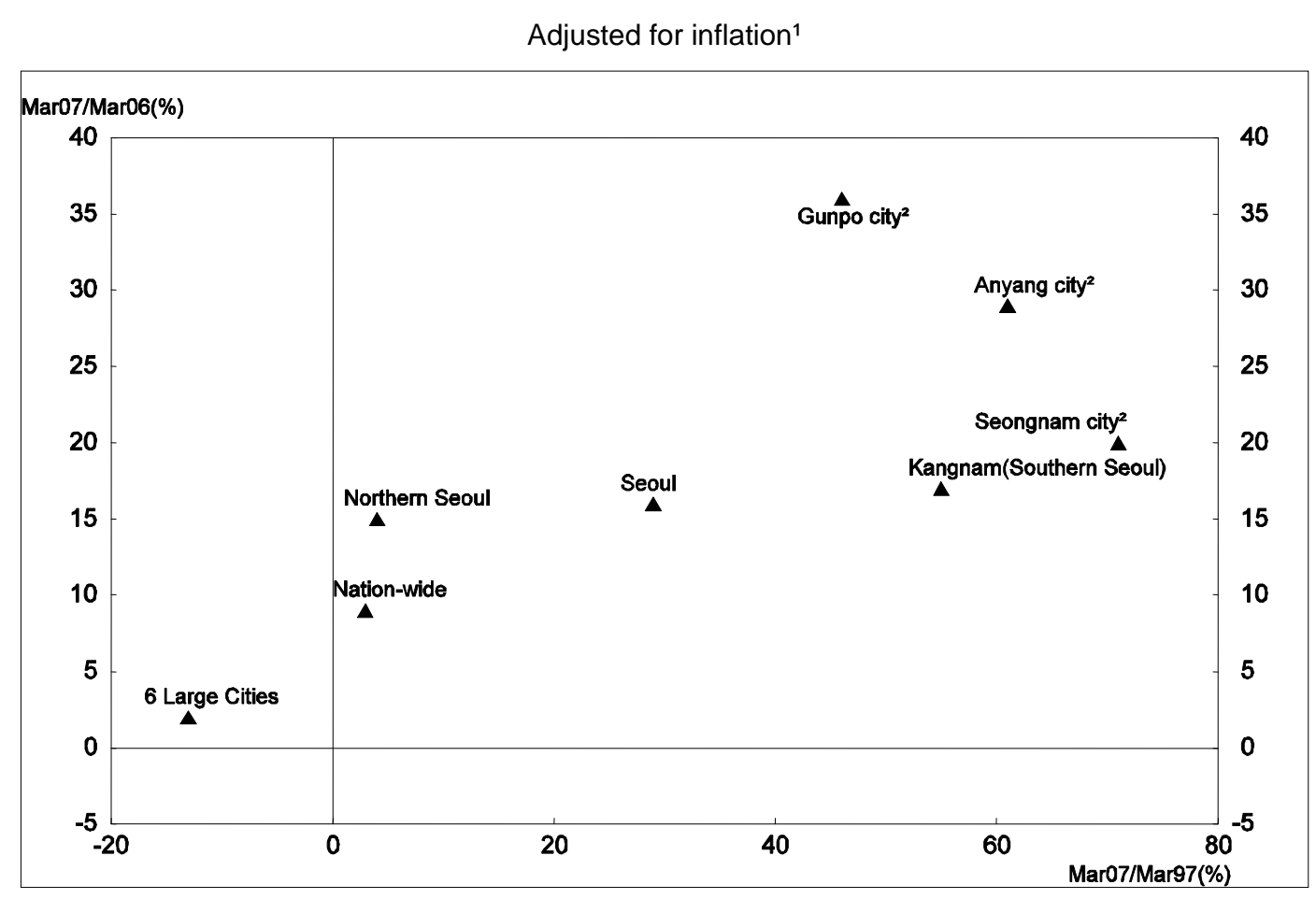

1. Housing purchase price composite index deflated by the overall consumer price index.

2. Anyang, Gunpo and Seongnam cities are all located in the southern suburbs of Seoul.

Source: Kookmin Bank and OECD, Economic Outlook database.

8. The relatively rapid rise in property prices in the southern part of Seoul results from several factors. First, there have been strong employment gains in Kangnam Ward, which is the centre of the Kangnam area, in sectors such as business services, finance and information and communication technology (ICT). Indeed, Kangnam Ward is the only one of the three major business centres in Seoul that has recorded employment growth since 1993, thanks to its central location, well-planned urban infrastructure and the government's past policies to induce industries into this area. The growth of employment had a positive impact on house prices (Kim and Lee, 2004). Second, Kangnam attracts families because of its high quality education. The government's policy of randomly allocating students to schools within each district encourages families to move to districts where the average performance of schools is higher. Kangnam also has a large number of outstanding after-school institutes (hakwon), further

5. Kangnam (south of the river), refers to the part of Seoul south of the Han River. At the centre of Kangnam is Kangnam-gu (ward), with a population of 0.5 million (5.2\% of Seoul and $2.3 \%$ of the capital region). 
increasing its popularity. Upward pressure on prices was magnified by government regulations introduced in March 2006 that made it difficult to redevelop apartments constructed 20 to 30 years ago in Kangnam, thus reducing supply.

9. Many other countries have also experienced sharp price increases in central districts of major cities, reflecting agglomeration economies and a low supply elasticity of housing due to space constraints. This trend seems to have accelerated in recent years due to the development of business services, ICT and financial services, which benefit significantly from agglomeration economies. ${ }^{6}$ Studies of urban housing in the United States have found that the low supply elasticity of housing units is an important factor behind recent large price increases (Girouard et al., 2006). House prices in some US cities have increased twice as fast as the nation-wide average during the past decade. Indeed, house prices in the New York City region increased $26 \%$ in real terms between mid-2004 and mid-2006. The history of rapid price gains creates expectations of future capital gains, thus effectively reducing the cost of buying houses in major cities.

\section{Volatility has been exacerbated by frequent policy changes and supply restrictions}

10. According to some studies, real house price movements are affected by structural factors, including institutional and tax changes, as well as by business cycles and interest rates. Frequent changes in real estate policies are thus a source of house price volatility. ${ }^{7}$ In addition, international experience shows that house prices are subject to larger swings in countries where housing supply is relatively inelastic (Catte et al., 2004).

11. Korea has been characterised by both frequent policy changes and inelastic housing supply. The authorities have been concerned that house price hikes in some areas will worsen income distribution by allowing "speculators" to benefit. ${ }^{8}$ This has led to a wide range of policies that are adjusted frequently to limit house price swings in the short run (see the 2005 OECD Economic Survey of Korea). In addition, land use is controlled by various regulations. For example, environmental rules and measures restrict construction to limit the concentration of population and economic activity in the capital region. Consequently, the relationship between house price variability and macroeconomic fluctuations, as measured by the output gap, is weak in Korea compared to other countries (Figure 5), suggesting that the supply elasticity is weak.

6. Le Bas and Miribel (2005) found stronger agglomeration economies from the geographical concentration of ICT industries as compared with non-ICT industries.

7. See Hannah, Kim and Mills (1993), Kim (2004), OECD (2005b) and Kim and Wachter (2006).

8. For example, the New Real Estate Reform policy of August 2005 states that "the government will cut off in advance any possibility of windfall income from real estate speculation to dent social cohesion". 
Figure 5. Correlation between real house prices and the business cycle

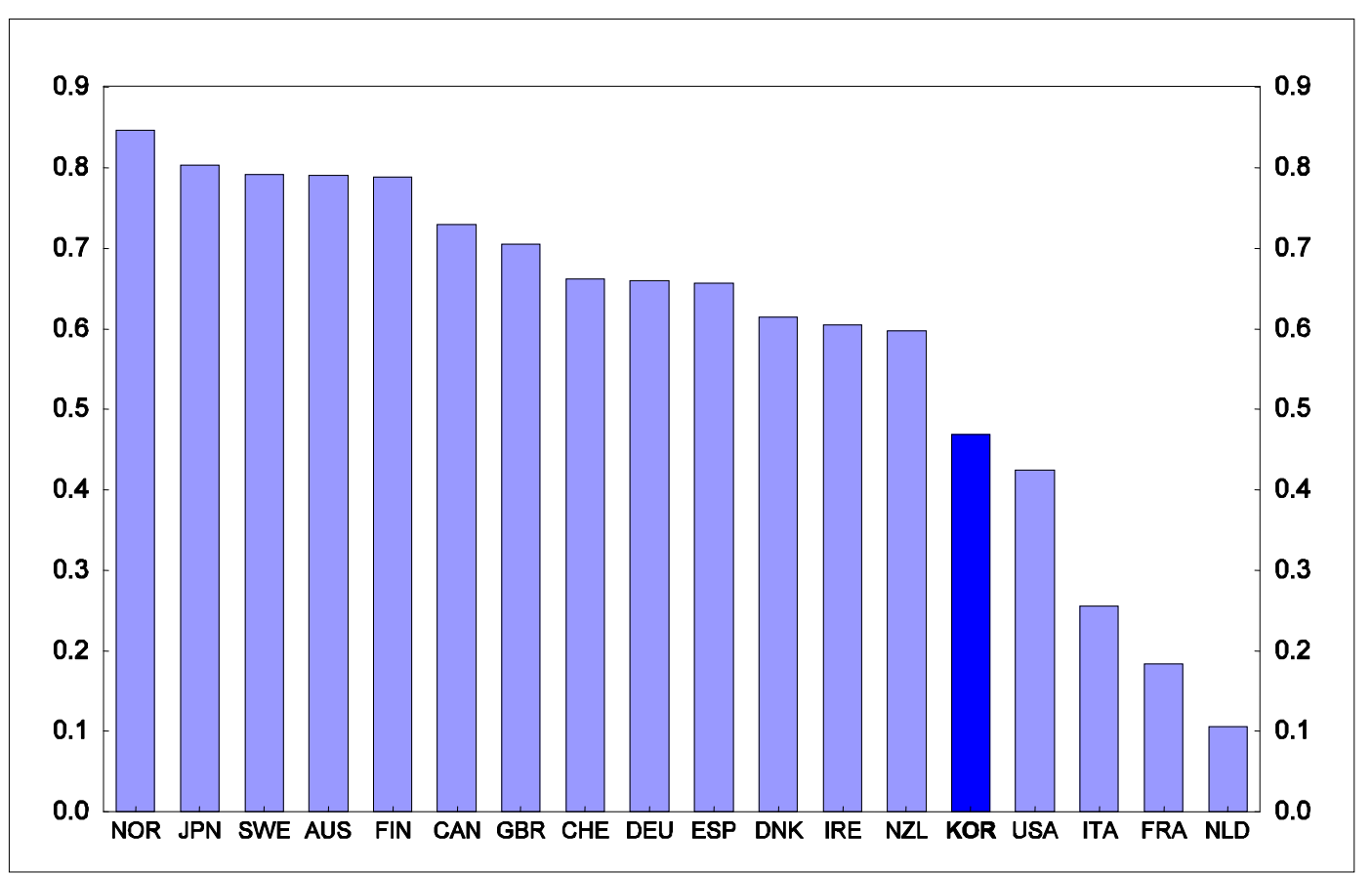

Note: Correlation is between de-trended real-house price levels and the output gap. It is calculated for the period 1986-2006, based on quarterly data.

Source: Girouard, N., M. Kennedy, P. van den Noord and C. Andre (2006), "Recent house price developments: the role of fundamentals", Economics Department Working Paper No. 475, OECD, Paris and OECD, Economic Outlook database.

12. Given the impact of frequent changes in real estate policy and the low supply elasticity of house prices, Korea has experienced relatively large house price fluctuations. Indeed, the standard deviation of house price changes was the fifth highest among the 17 OECD countries for which data are available in the 1993-99 period and fourth highest in the 2000-06 period (Figure 6), even though the rate of price increase was relatively low in Korea (Panel B). ${ }^{9}$ Greater volatility is generally observed in countries that have experienced higher price increases (Panel C). Korea thus stands out by having both relatively low price increases and high volatility. In sum, frequent real estate policy changes and limits on land use in the capital region have amplified fluctuations in house prices, thus magnifying the capital gains that the government wanted to avoid. To stabilise the housing market, the government launched a series of packages beginning in August 2005.

\section{Policies to stabilise property prices}

13. The five government real estate policy packages during the past 18 months are outlined in Annex A1. Despite the August 2005 and March 2006 packages, house price increases accelerated during 2006, prompting another package in November. However, the pace of increase picked up even further during the last two months of 2006, leading to additional policy measures in January 2007. The main features of the real estate policy packages are summarised in Box 1.

9. The decline in the 1993 to 1999 period reflects the supply of 2 million houses in the capital region in the early 1990s and the sharp fall in house prices in 1998 in the wake of the financial crisis. 
Figure 6. International comparison of variability in house prices

House prices deflated by the overall consumer price index ${ }^{1}$

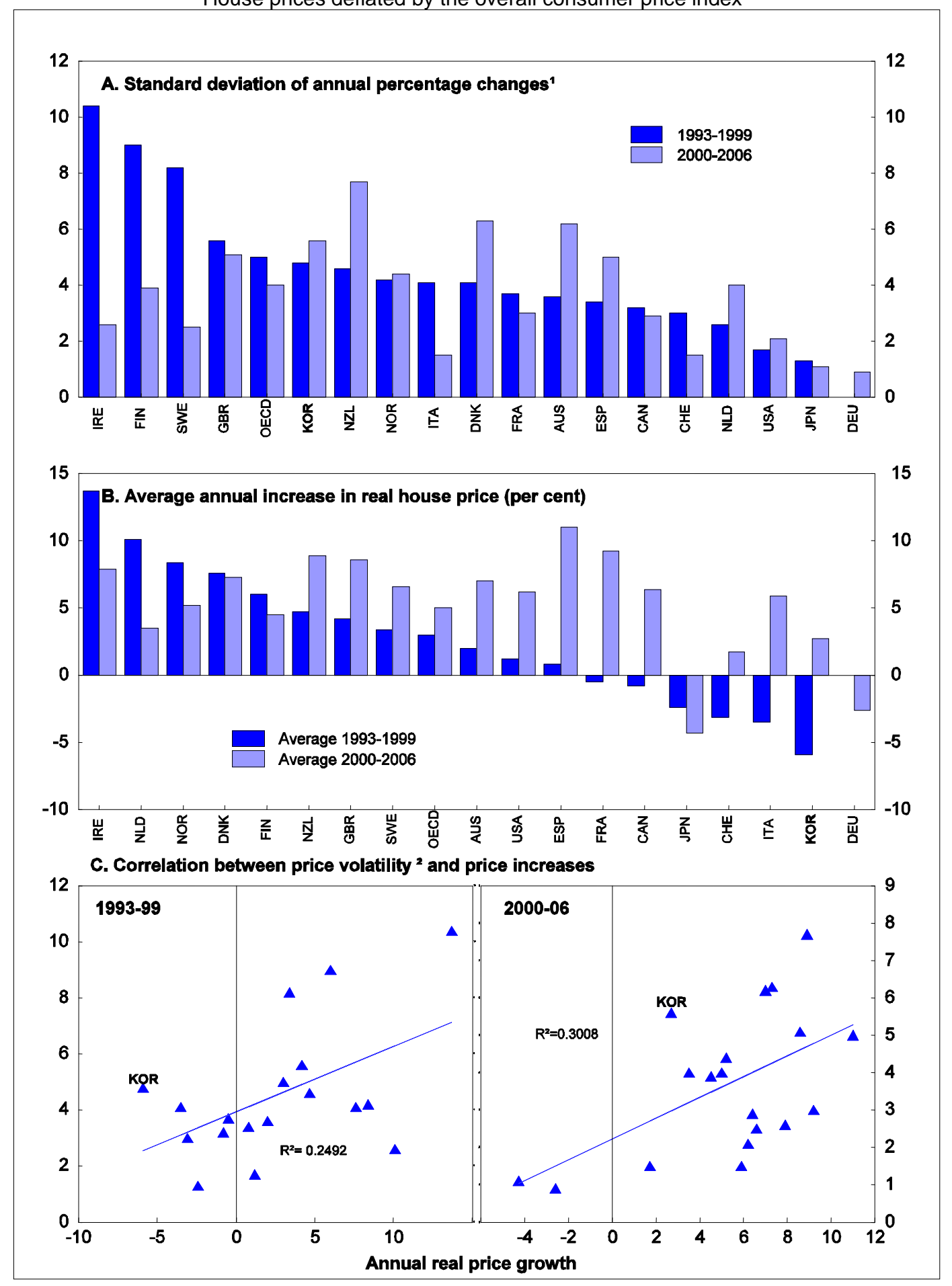

1. Countries are ranked by the level of variability in house prices (Panel $A$ ) and the overall increase in house prices (Panel B) over the period 1993-1999.

2. Price volatility measured as standard deviation of annual price growth ( $\mathrm{Y}$ axis).

Source: Girouard, N., M. Kennedy, P. van den Noord and C. Andre (2006), "Recent house price developments: the role of fundamentals", Economics Department Working Paper No. 475, OECD, Paris. 


\section{Box 1. Key elements of the real estate policy packages since 2005}

\section{Increase the supply of housing}

- $\quad$ Build 2.6 million public rental housing units over the next decade, increasing the stock from 0.8 million in 2006 (6\% of the total housing stock) to 3.4 million in $2017(20 \%)$. This will be partly financed by a rental housing fund that will amount to 90 trillion won (10\% of GDP).

- Expand the planned supply of houses for sale from 1.515 million units to 1.64 million units by 2010 by increasing public-sector construction by 125 thousand units. In sum, 867 thousand housing units are to be built on public land and 773 thousand units on privately-owned land.

- $\quad$ Secure additional land for housing by relaxing regulations, such as the floor-space to land ratio.

- Expand the National Housing Fund from 22.4 trillion won to 31 trillion won (4\% of GDP) in order to help lowincome households rent or purchase houses.

- $\quad$ Increase the supply of public rental housing by building additional National Rental Housing Complexes.

- Use regulatory changes and tax incentives to encourage private-sector supply of rental housing.

\section{Reduce demand for housing}

- Tighten restrictions on home-backed loans from financial institutions to reduce lending for homes valued at more than 600 million won (about $\$ 650$ 000):

a) Lowering the ceiling on the loan-to-value (LTV) ratio from $60 \%$ to $40 \%$ for loans by banks and insurance companies and to $50 \%$ for non-bank financial institutions in "speculation zones".

b) Expanding the coverage of the debt-to-income (DTI) ratio of $40 \%$ to loans for the purchase of an apartment valued at more than 600 million won in the capital region and in the speculation zones.

- Limit mortgage loans in speculation zones to only one per person.

- Require purchasers of homes in certain areas to report to local governments how they will finance the purchase and whether they will live in the home.

- Ban the re-sale of all new houses in the capital region for five to seven years after purchase, depending on the size of the unit. Previously, this regulation applied only to homes built by the public sector.

- $\quad$ Strengthen monitoring by the National Tax Service (NTS) of owners of more than three properties.

- Impose charges (a quasi-tax) of up to $50 \%$ on redevelopment gains.

- $\quad$ Disperse housing demand by promoting balanced regional development throughout the country by creating innovation cities and enterprise cities and encouraging the development of lagging regions in urban areas.

\section{Cut the price of housing}

- Lower the prices of new apartments in the capital region by $25 \%$ by increasing the ceiling on the floor space to land ratio, changing the land price calculation method to lower its price and shortening the housing construction period. 
- $\quad$ Reduce housing prices nation-wide by around $20 \%$ by:

a) Requiring private-sector builders to publicly disclose their construction costs for housing projects in the capital region (such a requirement is already applied to government-run housing projects). Price Audit Committees under local governments will review the information on construction costs.

b) Having local governments set price ceilings on new houses nation-wide based on the construction costs, the assessed value of the land and a proper level of profit, in the view of the local government.

- Tighten regulations on the re-construction of apartments, which typically leads to an increase in their price.

Reform the property-related tax system to curb speculative demand by increasing the tax burden on highpriced houses and multiple home owners

1. Speculation zones are designated by the Ministry of Finance and Economy after review by the "Property Price Review Committee". To be designated as a speculation zone: 1) the monthly house price increase must be $30 \%$ more than the inflation rate; and 2) the house price increase during the past two months must be $30 \%$ more than the nation-wide average or the annual price increase must be more than the average nation-wide price increase during the past three years. Currently, 92 regional districts (37\% of the total) are designated as speculation zones, covering most of the capital region and urban areas elsewhere in the country. In speculation zones, the LTV ceiling is set at $40 \%$, the DTI ceiling of $40 \%$ is applied to houses that cost more than 600 million won, housing loans are limited to one per person, taxation is heavier and transactions are subject to a reporting requirement.

\section{Increasing supply and providing financing}

14. The increased emphasis on expanding the supply of housing in the November 2006 package is welcome. While the large increase in supply in the early 1990s led to a long period of declining prices in real terms, the smaller pace of housing construction in recent years puts upward pressure on prices. According to the plan, new houses will be built in the capital region, while the government maintains its objective of balanced regional development.

15. The most recent initiative to build public rental housing will significantly boost the supply of housing. In $2005,56 \%$ of Korean households owned residences, while $19 \%$ had monthly rental contracts. ${ }^{10}$ The government's plan will boost public rental housing from $6 \%$ of the country's total housing stock, which is below the level in some advanced OECD countries, to $20 \%$. The government believes that the private rental housing market does not function well, thus requiring the public sector to ensure housing for low-income persons. The rental housing fund, which is to finance 0.5 million rental housing units, will be financed by public financial institutions, such as the National Pension Fund, Postal Savings and agricultural co-operatives, and private investors. The rental housing fund will guarantee a return that is slightly above that on government bonds. The risk-free premium available on such investment may crowd out investment in private bonds, thereby driving up the corporate bond rate in the longer term. The leading role assigned to the public sector in increasing housing supply creates other concerns. In particular, the government's plan to supply such a large amount of rental housing in the capital region will absorb a significant share of the available land and crowd out private-sector rental housing. While the stock of public rental housing is relatively low and the demand for rental housing is rising, the increase in the public rental housing stock may be too sharp in the context of rising income and the preference for house ownership.

10. The remaining $25 \%$ lived in homes leased under "chonsei" contracts. Under the chonsei system, the tenant pays a deposit equivalent to about half of the house price instead of monthly rental payments. This allows households to live in homes that they are not able to purchase. 
16. The government also plans to expand its role in providing land for housing construction, given the regulations on land use. For example, "public-private joint projects" announced in January 2007 utilise the government's expropriation power to obtain land. This will contribute to increasing housing supply in the capital region. The government intends to use this land for low-cost housing but at the same time it allows private construction companies to build houses of their own choice. However, the equity concerns that emphasise low-cost housing create risks of failing to match consumers' preferences, as reflected in the fact that prices are increasing most rapidly for houses at the upper end, rather than the lower end of the market. In sum, while the government has a role to play in providing housing for low-income households and overcoming regulations that limit the availability of land, relaxing regulations on land use and emphasising the role of the private sector is essential to meet consumers' preferences.

17. A greater role for the private sector in the housing market would increase the responsiveness of supply to changes in price. A unique feature of Korea's situation is that rising house prices during the past 18 months have coincided with a downturn in construction activity, suggesting a low price elasticity of supply. A more important role for the private sector in housing would require liberalisation of the regulations on land use, which is governed by 112 different laws that are administered by a number of different ministries. The complicated patchwork of regulations, which have been improved by the recently introduced Land Use Regulation Rationalisation Act, should be simplified further. Moreover, there is a lack of transparency given that there is no comprehensive database on these regulations. In addition, it is important to remove regulations that restrict housing supply. For example, the reconstruction of old apartments in the Kangnam area has recently been restricted through planning and building regulations, which appear to be strengthening upward pressure on prices. The government argues, though, that allowing reconstruction of more housing units would spark new demand and higher prices in the short run - which could spread to other parts of the country - until the additional units are available. ${ }^{11}$ However, the limits on supply create expectations of future price increases, boosting demand for housing, although the higher property-related taxes should reduce demand.

\section{Policies to restrict demand: reducing bank lending and cracking down on "speculators"}

18. The authorities are concerned about the rising trend of mortgage lending by the banking sector, which expanded from 55 trillion won in 2000 (10\% of GDP) to 217 trillion won (26\% of GDP) in December 2006, excluding public financial institutions. The mortgage market used to be dominated by the government's National Housing Fund and the Korea Housing Bank, which lent to low and middle-income households. Following financial deregulation in the early 1990s and the privatisation of the Korea Housing Bank in 1997, the private mortgage market expanded sharply (Kim, 2004). Moreover, the business strategy of banks focused increasingly on households following the crisis, as large firms have gone through a period of de-leveraging and subdued investment activity, while smaller companies have become increasingly indebted, making further lending risky. Nevertheless, the government has criticised the increase in mortgage lending and made it a goal to cut "irrational" housing lending, on the grounds that it fuels speculation while putting the soundness of financial institutions at risk. ${ }^{12}$ However, the total level of mortgage debt, including the public sector, was 34\% of GDP in 2005, well below the OECD average of $56 \%$ (Figure 7). Mortgage debt, at $42 \%$ of total household debt, is relatively low by international comparison (Panel B).

11. The government set two conditions for easing regulations on the reconstruction of old apartments in August 2005 - price stability and the ability of the government to retrieve the development gains from reconstruction. This second condition was met with the imposition of charges (a quasi-tax) up to $50 \%$ of re-development gains in March 2006.

12. The authorities view the relatively small increase in mortgage lending rates - of 50 basis points since August 2005 - while the short-term policy rate rose 125 basis points, as evidence of excessive competition. 
Figure 7. International comparison of mortgage debt in 2005

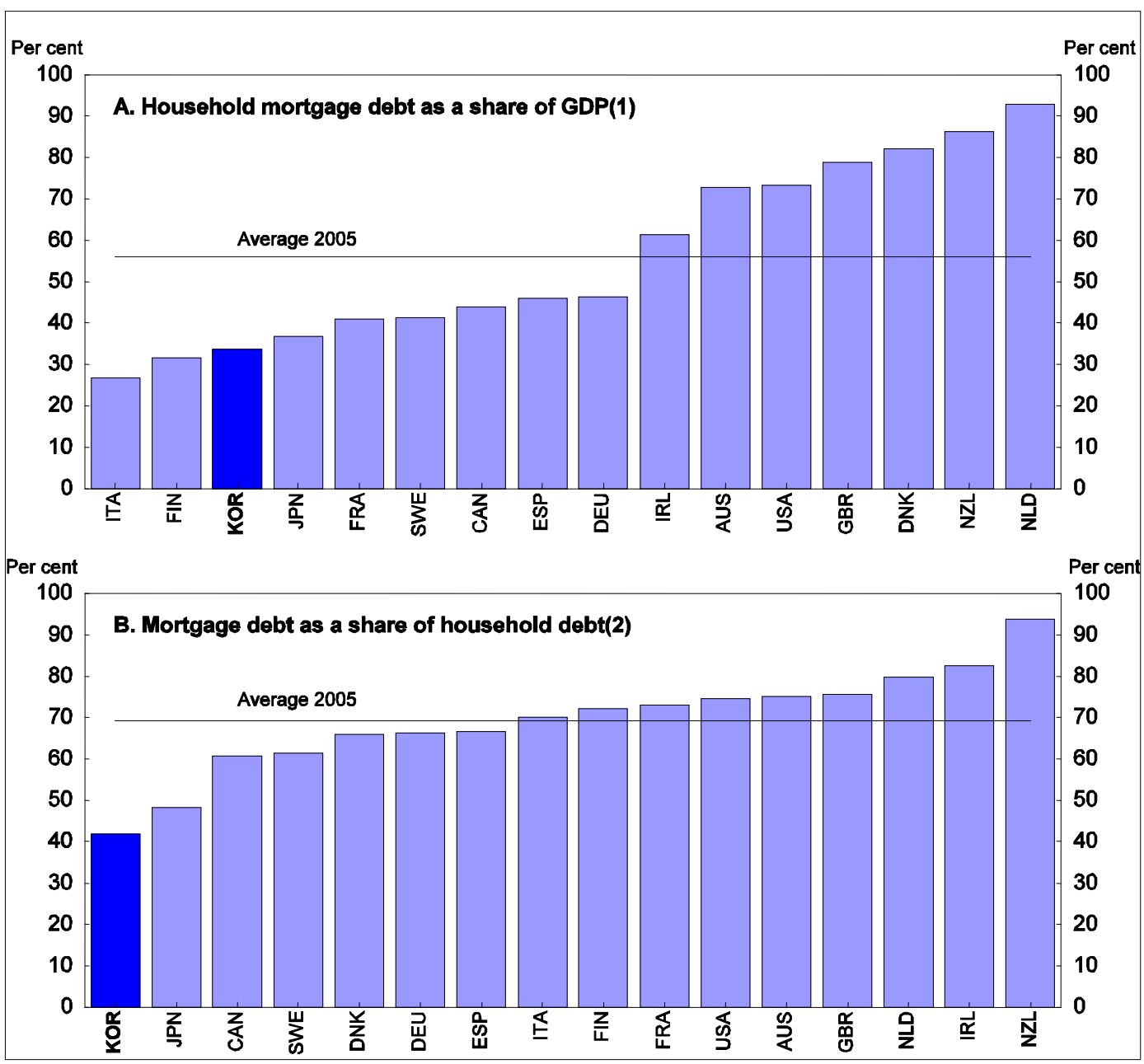

1. 2004 for Japan and Spain.

2. 2004 for Japan, Denmark and Spain.

Source: OECD Economic Outlook, No. 80, Financial Supervisory Service and the Bank of Korea.

19. The authorities have taken a number of steps to slow the growth of mortgage lending. First, the Financial Supervisory Service (FSS) has reduced the maximum loan-to-value (LTV) ratio for housing loans in "speculation zones", which includes most of the capital region, from $60 \%$ to $40 \%$. The LTV ratio is a key indicator of the mortgage market's ability to provide access to financing. The typical LTV ratio in OECD countries is between $55 \%$ and $90 \%$, with the maximum range for the ratio going up to between $80 \%$ and $115 \%$ (Catte et. al., 2004). Many countries do not even have restrictions on the LTV ratio and, among those that do, the ceiling is generally much higher than in Korea (Table 1). In addition, regulations on LTV ratios in other OECD countries influence the availability of loans by changing borrowing costs based on the LTV ratio, whereas Korea imposes this restriction uniformly by administrative guidance on financial institutions. Second, the FSS imposed a ceiling of $40 \%$ on the debt-to-income ratio - principal and interest payments on total loans as a share of income - in most of the capital region. Third, the authorities raised the minimum provisions for bank loans classified as normal and precautionary, a move that is expected to raise bank provisioning by up to 2.5 trillion won. ${ }^{13}$ Following the introduction of tighter regulations, a number of banks have reined in lending for housing, and one temporarily ceased such lending.

13. Banks' loan-loss provisions totalled 7.7 trillion won in 2005. 
Table 1. Regulatory limitations on loan-to-value ratios

\begin{tabular}{|c|c|c|c|c|}
\hline & $\begin{array}{c}\text { Property } \\
\text { valuation method }\end{array}$ & $\begin{array}{l}\text { Restrictions on } \\
\text { valuation method }\end{array}$ & $\begin{array}{l}\text { Regulatory limits } \\
\text { on loan-to-value }\end{array}$ & Link with capital adequacy \\
\hline Australia & OMV & $\mathrm{Y}$ & $\begin{array}{l}80 \%(100 \% \text { if } \\
\text { insured })\end{array}$ & $\begin{array}{l}50 \% \text { weight, subject to insurance } \\
\text { if loan is above } 80 \% \text { limit }\end{array}$ \\
\hline Belgium & OMV/MLV & $\mathrm{N}$ & None & $\begin{array}{l}50 \% \text { weight, subject to prudent } \\
\text { valuation of collateral }\end{array}$ \\
\hline Canada & OMV (or variant) & $\mathrm{N}$ & $\begin{array}{l}75 \%(95 \% \text { if } \\
\text { insured) }\end{array}$ & $\begin{array}{l}50 \% \text { weight if loan is up to } 75 \% \\
\text { limit; } 0 \% \text { weight if CMHC-insured }\end{array}$ \\
\hline Denmark & n.a. & n.a. & $80 \%$ & None \\
\hline Finland & n.a & n.a. & None & None \\
\hline France & OMV & Y & $\begin{array}{l}60 \% \text { to be eligible } \\
\text { for mortgage- } \\
\text { backed securities }\end{array}$ & None \\
\hline Germany & MLV & $\mathrm{Y}$ & $\begin{array}{l}60 \% \text { to be eligible } \\
\text { for mortgage- } \\
\text { backed securities }\end{array}$ & $\begin{array}{l}50 \% \text { weight for first mortgages if } \\
\text { loan is up to } 60 \% \text { limit }\end{array}$ \\
\hline Ireland & OMV & $\mathrm{N}$ & $\begin{array}{l}80 \% \text { (only for } \\
\text { building societies) }\end{array}$ & None \\
\hline Italy & OMV & $\mathrm{N}$ & $\begin{array}{l}80 \%(100 \% \text { if } \\
\text { guaranteed })\end{array}$ & $\begin{array}{l}50 \% \text { weight if loan is up to } 80 \% \\
\text { limit }\end{array}$ \\
\hline Japan & n.a. & $\mathrm{N}$ & None & $50 \%$ weight for first mortgages \\
\hline Korea & OMV & $\mathbf{Y}$ & $40-60 \%$ & \\
\hline Netherlands & OMV & $\mathrm{N}$ & None & $\begin{array}{l}50 \% \text { weight for part of the loan } \\
\text { up to } 75 \% \text { of collateral; } 0 \% \\
\text { weight if NHG-insured }\end{array}$ \\
\hline Spain & $\begin{array}{l}\text { Prudent valuation } \\
\text { certified by } \\
\text { appraiser }\end{array}$ & Yes & $\begin{array}{l}80 \% \text { to be eligible } \\
\text { for mortgage- } \\
\text { backed securities }\end{array}$ & $\begin{array}{l}50 \% \text { weight, subject to prudent } \\
\text { valuation of collateral }\end{array}$ \\
\hline Sweden & OMV & No & None & $\begin{array}{l}50 \% \text { weight if loan is up to } 100 \% \\
\text { of collateral }\end{array}$ \\
\hline Switzerland & $\begin{array}{l}\text { Mortgage lending } \\
\text { value }\end{array}$ & n.a. & None & $\begin{array}{c}50 \% \text { weight up to } 2 / 3 \text { of market } \\
\text { value; } 75 \% \text { weight above that } \\
\text { limit }\end{array}$ \\
\hline United Kingdom & OMV & No & $\begin{array}{l}100 \% \text { (only for } \\
\text { building societies) }\end{array}$ & $\begin{array}{c}50 \% \text { weight if loan is up to } 90 \% \\
\text { of collateral; } 60 \% \text { weight above } \\
\text { that limit }\end{array}$ \\
\hline United States & OMV & $\begin{array}{l}\text { No (but appraisers } \\
\text { need to be } \\
\text { certified) }\end{array}$ & $\begin{array}{l}90 \% \text { if not } \\
\text { guaranteed }\end{array}$ & $\begin{array}{c}50 \% \text { weight if loan is up to } 90 \% \\
\text { of collateral; } 100 \% \text { weight above } \\
\text { that limit }\end{array}$ \\
\hline
\end{tabular}

Note: $\mathrm{OMV}=$ Open market value; MLV = Mortgage lending value. The MLV must be based on a prudent assessment of the market value (in Germany the typical adjustment factor is 20-25\%).

Source: Catte et al. (2004). 
20. The authorities have taken a number of additional steps to reduce demand. Purchasers of homes are being required to report to local governments how they will finance the purchase and whether or not they will live in the home. In addition, the re-sale of all new houses in the capital region is banned for five to seven years after purchase, depending on size, as a way of ensuring that gains do not go to speculators. However, such measures limit property rights that are essential in market economies. Finally, in 2005, tax authorities investigated owners of more than three properties that are "suspected of speculation".

\section{Policies to reduce prices}

21. The government plans to reduce the prices of new apartments in new towns by $25 \%$ through regulatory changes and accelerated construction (Box 1). In addition, it expects to reduce the price of new homes built by private firms by $20 \%$ by setting price caps, based on the public disclosure of the firms' construction costs. This initiative reflects the government's perception that houses are overpriced because of persistent and restrictive regulations on land use. Such a policy has to be seen in the context of the government's objective to limit the large house swings in the short run. Despite the merits of such a policy objective, it may have the potential to create substantial harm if allowed to persist in the longer term. First, requiring private firms to publicly disclose construction costs, along with the price caps set by local governments, removes incentives to increase profits by reducing costs. Second, local governments will decide the appropriate level of profit in setting the price cap. Setting it at a low level, in line with the objective of reducing prices by one-fifth, would reduce investment in housing. The impact may be most severe in the high-end market, which has higher profit margins and faster-growing demand. Given these considerations, the government should phase-out housing price controls in the longer term, as regulatory changes are implemented and housing supply becomes more elastic. This would further increase housing supply. Finally, the government should also ensure that there is enough competition in the market.

\section{Reform of taxes on property}

22. The government has been taking steps to reform property taxes with a focus on enhancing fairness and stabilising the property market. The major changes have been to reduce the tax burden on acquisitions, raise the burden on property holdings and increase the capital gains tax. The registration tax on real estate transactions was reduced from $3 \%$ to $1 \%$ in 2006, while the acquisition tax was cut from $2 \%$ to $1 \%$, which should facilitate transactions and encourage mobility. As for taxes on property holding, recurrent taxes on property amount to $0.5 \%$ of GDP, well below the OECD average (Figure 8), reflecting a low effective tax rate of $0.1 \%$ of market value in 2005. The government has a target of raising the effective rate to around $1 \%$ by 2017 . One step toward that goal was to bring the evaluation of real estate for tax purposes closer into line with market values. The evaluation - the application ratio - was increased from $36 \%$ of the value of housing assessed by the Ministry of Construction and Transportation (MCT) to 50\% in 2005. Given that the MCT assessed value is about $80-90 \%$ of the market price, the tax base has risen from $29-32 \%$ of the market value to $40-45 \%$. 
Figure 8. Recurrent taxes on immovable property in OECD countries

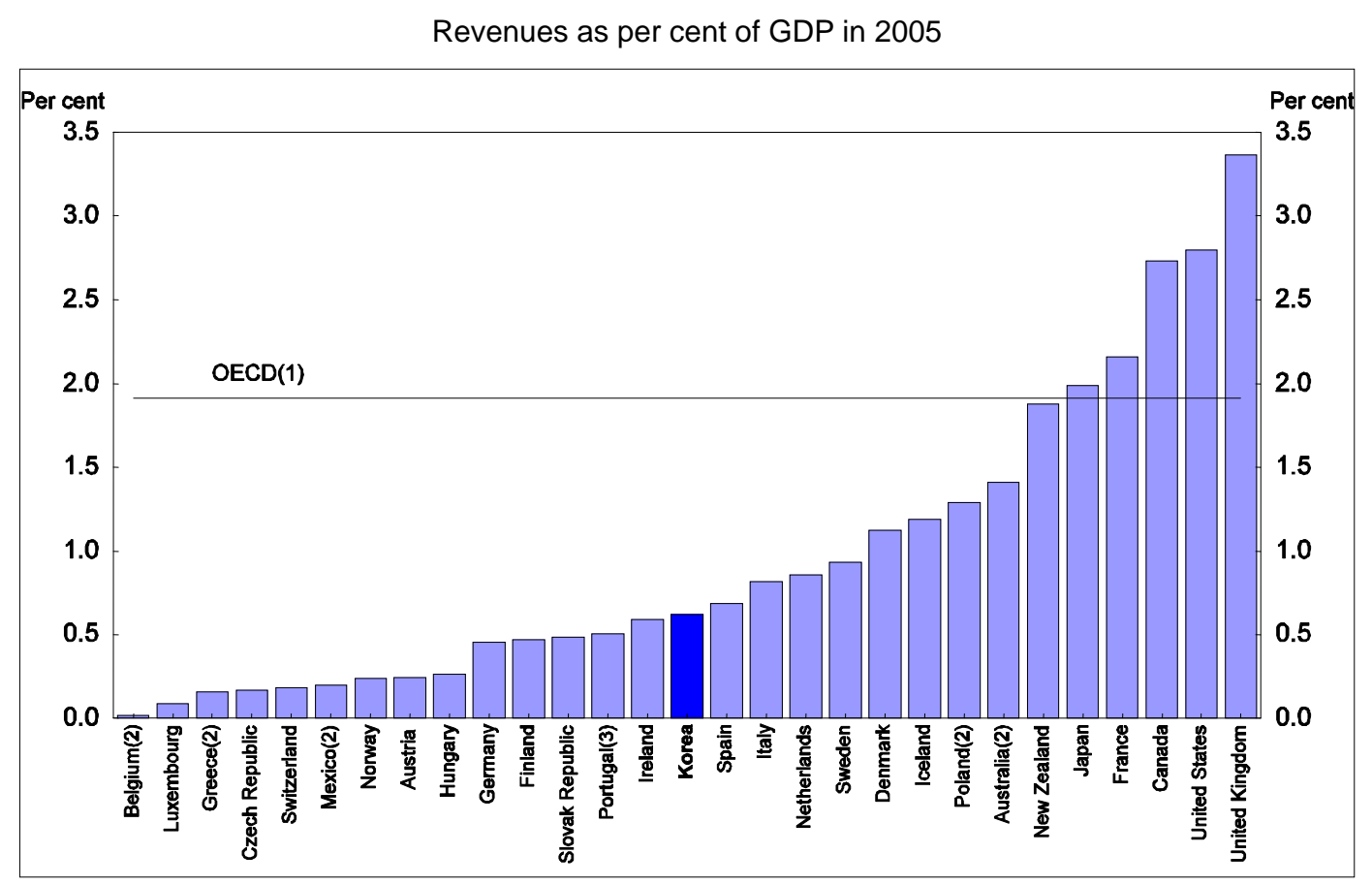

1. Weighted average using 2000 GDP and purchasing power parity exchange rates.

2. 2004 data.

3. 2003 data.

Source: OECD (2006), Revenue Statistics, 1965-2005, OECD, Paris.

23. The local tax on property, which had imposed separate taxes on housing (six rates between $0.3 \%$ and $7 \%$ ) and on the attached land (nine rates between $0.2 \%$ and 5\%), was combined in 2005. The new tax has three rates, ranging from $0.15 \%$ and $0.5 \%$ (Table 2 ). To maintain the progressivity of taxes on property holding, the Comprehensive Property Tax (CPT), a national tax, was introduced in 2005. The tax is applied to households and companies owning housing with a combined assessed value of more than 600 million won (about $\$ 650000$ ). The tax rate varies from 1\% to 3\%, as part of the long-run effort to raise the effective tax rate on property. In addition, the higher tax rate is intended to stabilise house prices by curbing "speculative demand". The new tax will also have a substantial impact on income re-distribution, given the progressivity in the tax rate and the 600 billion won threshold. In 2006, 237 thousand households (1.3\% of the total) were subject to the CPT. The tax base was increased from $50 \%$ of the assessed value in 2005 to $70 \%$ in 2006, resulting in sharp increases in property tax assessments for some households. ${ }^{14}$ As a result, the revenue from the CPT increased from 0.4 trillion won in 2005 to 1.3 trillion won $(0.2 \%$ of GDP) in 2006. The combined effect of the two systems is a very progressive tax system. Indeed, the effective rate on households not subject to the CPT is less than $0.2 \%$ (Figure 9), but rises steadily to $0.8 \%$ for those with houses valued at 2.4 billion won ( $\$ 2.5$ million).

14. Other changes in the CPT that took effect in 2006 concerning housing: $i$ ) the tax is imposed on a household's total properties rather than on each individual's; ii) the tax is levied on the excess of the government-assessed value over 600 million won instead of 900 million won; and iii) the maximum increase in a tax liability is $300 \%$ from the preceding year rather than $150 \%$. 
ECO/WKP(2008)21

Table 2. Property holding taxes in Korea

\begin{tabular}{|c|c|c|c|c|c|c|}
\hline & \multicolumn{3}{|c|}{ Local property tax } & \multicolumn{3}{|c|}{ National Comprehensive Property Tax ${ }^{1}$} \\
\hline & Housing & $\begin{array}{l}\text { Land for } \\
\text { business }\end{array}$ & $\begin{array}{l}\text { Land for } \\
\text { non- } \\
\text { business }\end{array}$ & Housing & $\begin{array}{l}\text { Land for } \\
\text { business }\end{array}$ & $\begin{array}{l}\text { Land for } \\
\text { non- } \\
\text { business }\end{array}$ \\
\hline Asset value threshold (won) & 0 & 0 & 0 & 600 million & 4 billion & 300 million \\
\hline Calculation of tax base & $\begin{array}{c}\text { Per } \\
\text { property }\end{array}$ & $\begin{array}{c}\text { Cumulative } \\
\text { value per } \\
\text { person }\end{array}$ & $\begin{array}{c}\text { Cumulative } \\
\text { value per } \\
\text { person }\end{array}$ & $\begin{array}{l}\text { Nation-wide } \\
\text { cumulative } \\
\text { value per } \\
\text { household }\end{array}$ & $\begin{array}{l}\text { Nation-wide } \\
\text { cumulative } \\
\text { value per } \\
\text { person }\end{array}$ & $\begin{array}{l}\text { Nation-wide } \\
\text { cumulative } \\
\text { value per } \\
\text { household }\end{array}$ \\
\hline Tax rates $^{2}$ & $\begin{array}{l}0.15 \text { to } \\
0.5 \%\end{array}$ & 0.2 to $0.4 \%$ & 0.2 to $0.5 \%$ & 1 to $3 \%$ & 0.6 to $1.6 \%$ & 1 to $4 \%$ \\
\hline $\begin{array}{l}\text { Ceiling on increase in tax } \\
\text { payment }\end{array}$ & $\begin{array}{l}105 \text { to } \\
150 \%\end{array}$ & $150 \%$ & $150 \%$ & $300 \%$ & $150 \%$ & $300 \%$ \\
\hline Application ratio ${ }^{4}$ & $50 \%$ & $60 \%$ & $60 \%$ & $80 \%$ & $60 \%$ & $80 \%$ \\
\hline $\begin{array}{l}\text { Year in which the application } \\
\text { ratio reaches } 100 \%\end{array}$ & 2017 & 2015 & 2015 & 2009 & 2015 & 2009 \\
\hline
\end{tabular}

1. Introduced in 2005. Revenues are redistributed to local governments.

2. There are three tax rates for each category except the Comprehensive Property Tax on housing, which has four.

3. Relative to the preceding year.

4. The proportion of the value assessed by the Ministry of Construction and Transport that is used as the tax base.

Source: Ministry of Finance and Economy.

24. Property taxation is theoretically more advantageous for local governments than other taxes as it is levied on immobile assets, thus limiting the scope for tax evasion. Although the basic direction of increasing property holding tax and reducing taxes on acquisition is in the right direction (see the 2005 OECD Economic Survey of Korea), there are a number of issues that should be considered in the longer term.

- Using property taxes for redistribution is inappropriate as it does not include other forms of wealth. Consequently, persons holding real estate are taxed more heavily than those who invested in other assets. Property taxes are usually based on the benefit principle, which stipulates that local taxes should reflect the use of local public services rather than residents' ability to pay.

- The use of two taxes - local and national - on property is a potential source of confusion. ${ }^{15}$ Moreover, the national property tax is redistributed to local governments, according to a formula that gives an $80 \%$ weight to their fiscal needs, further undermining the benefit principle.

- Changes in the property tax system should be made from an efficiency perspective rather than as a tool to control short-term price fluctuations.

15. The Swedish tax system imposes a property tax at the national level but not at the local government level. However, the government plans to abolish this tax and will consider the introduction of some form of property taxation at the local level in the coming years. Nevertheless, the Korean government intends to maintain the CPT as a national tax due to its concern about the strong tendency of some revenue-rich local governments to undermine the central government's initiative of raising the effective tax rate on property holding. 
Figure 9. Effective tax rate on property holding in Korea

Per cent of market value based on 2007 tax code

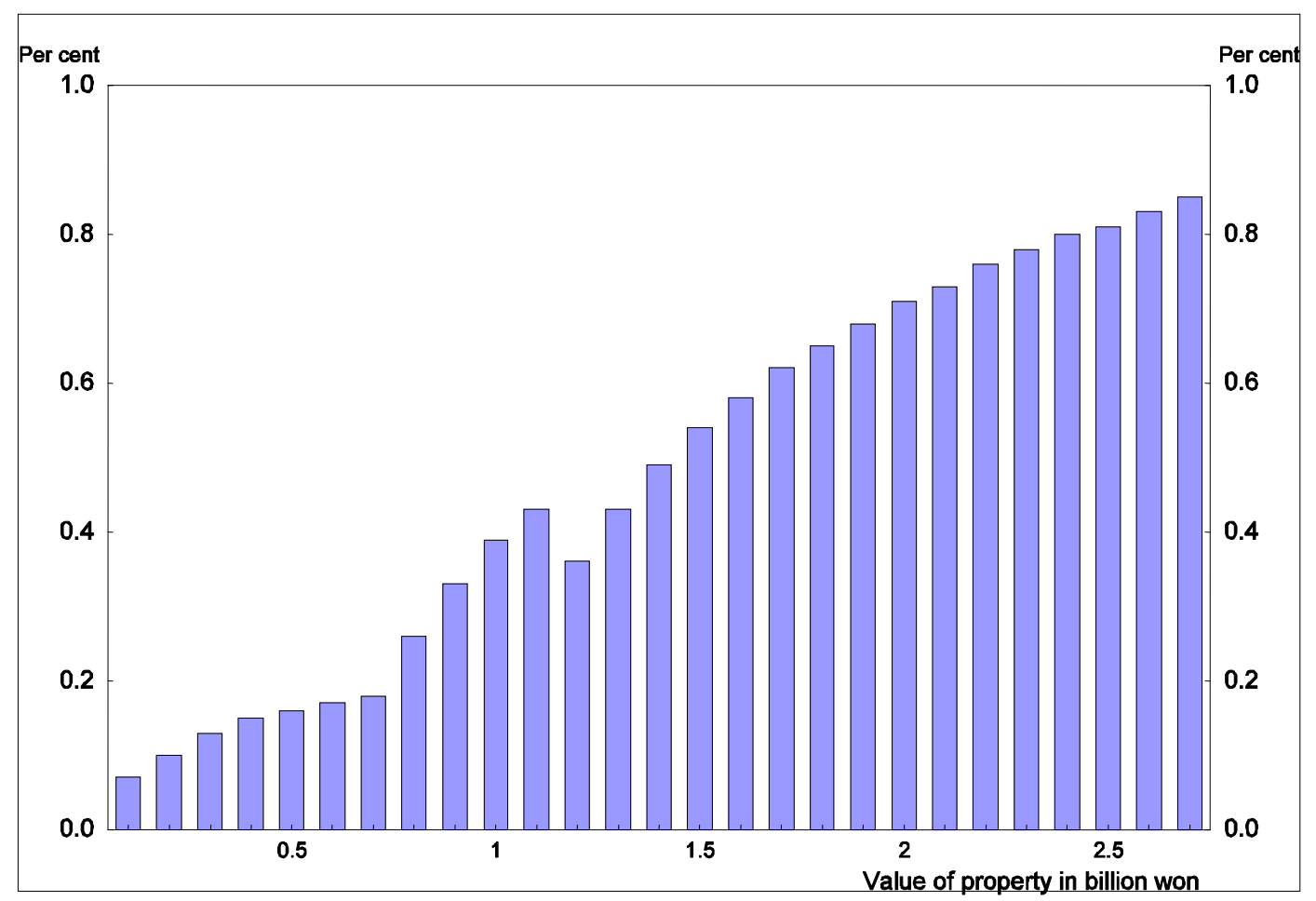

Source: OECD calculations.

25. Finally, the question of property tax is linked to the issue of fiscal decentralisation. Some local governments in the capital region that are already running surpluses have cut their property tax rates as the increase in the tax base boosted their revenue, thus undermining the government's goal of raising the effective tax rate on property. This choice reflects the limited spending responsibilities of local governments. Indeed, key services such as education and police services are funded primarily by the central government (see below). Consequently, achieving a significantly higher effective rate on property is linked to fiscal decentralisation to give more spending responsibilities to local governments.

26. As for the capital gains tax on real estate, it depends on the length of ownership and the number of houses owned. Single homeowners are exempted from the tax on the sale of a home, owned at least three years, which does not exceed 600 million won. The normal tax rate ranges from $9 \%$ to $36 \%$ depending on the size of the capital gain. The rate increases to $50 \%$ for property held less than one year, and $40 \%$ for that held one to two years (Table 3). Two recent changes have boosted the effective rate as part of the government's effort to discourage speculation by taxing away more of the gains. First, in the past, capital gains were calculated based on the value assessed by the NTS, which was $50-70 \%$ of the market value. Beginning in 2007, actual sales prices are used instead for all homes. ${ }^{16}$ Second, the government has focused higher capital gains taxes on persons who own more than one dwelling. A rate of

16. The use of the actual sales price was introduced for homes valued at more than 600 million won (from 1999), households owning three or more homes (from 2004) and households owning two or more homes (from 2006). 
$60 \%$ was imposed in 2005 on those owning three or more houses, with some exceptions. ${ }^{17}$ Furthermore, a rate of 50\% on those with two houses was announced in August 2005 and introduced in 2007. The early announcement had the expected impact of encouraging multiple home owners to sell before the rate was increased.

Table 3. Recent changes in the capital gains tax on property in Korea

\begin{tabular}{|c|c|c|}
\hline Situation & Tax rates through the end of 2006 & $\begin{array}{l}\text { Tax rates beginning } \\
\text { in } 2007\end{array}$ \\
\hline Normal tax rates ${ }^{1}$ & $\begin{array}{l}9 \% \text { for taxable gain up to } 10 \text { million won } \\
18 \% \text { for taxable gain of } 10 \text { to } 40 \text { million won } \\
27 \% \text { for taxable gain of } 40 \text { to } 80 \text { million won } \\
36 \% \text { for taxable gain above } 80 \text { million won }\end{array}$ & No change \\
\hline Owned less than 1 year & $50 \%$ & No change \\
\hline Owned 1 to 2 years & $40 \%$ & No change \\
\hline Unregistered property & $70 \%$ & No change \\
\hline Households owning 3 or more homes ${ }^{2}$ & $60 \%^{3}$ & No change \\
\hline Households owning 2 homes ${ }^{3}$ & Normal tax rate $(9 \%$ to $36 \%)$ & $50 \%{ }^{4}$ \\
\hline Land held for non-business purposes & Normal tax rate $(9 \%$ to $36 \%)$ & $60 \%{ }^{4}$ \\
\hline
\end{tabular}

1. Applies to households with one home with a selling price of more than 600 million won (about $\$ 650000$ ), which accounts for $2-3 \%$ of total homes in Korea. The taxable gain is calculated as:

$[(S-600 \text { million }) / S]^{*}(S-P)$, where $S$ is the selling price and $P$ is the purchase price. Thus, if the selling price were 1.8 billion won and the purchase price were 1 billion won, the taxable gain would be 0.53 billion won.

2. In addition, the special deduction in the capital gains tax for long-term ownership, which can go as high as $30 \%$, is eliminated for multiple homeowners in 2007.

3. Introduced in 2005

4. Announced in August 2005.

Source: Ministry of Finance and Economy.

27. The recent changes in the capital gains tax raise a number of concerns:

- The sharp increase in the capital gains tax, particularly with regard to multiple home owners, runs counter to the principle of lowering taxes on property transactions, and thus has a lock-in effect that blocks the supply of homes. ${ }^{18}$ In addition, higher capital gains taxes may boost house prices, given that supply appears to be inelastic in the short run.

- The wide variation in tax rates applied to gains of similar size creates equity issues. For example, a person owning five or more dwellings can be treated as a rental business and subject to the normal capital gains tax rate ranging from $9 \%$ to $36 \%$, while persons owning three or four dwellings pay $60 \%$.

17. A normal tax rate of $9 \%$ to $36 \%$ is applied to those who rent five or more houses and meet the following conditions: $i$ ) the houses must all be located in the same city or county; $i i$ ) the houses must be rented for ten years or longer; iii) the size of each of these rented houses must be 85 square metres or less; $i v$ ) the value of each of the rented houses cannot exceed 300 million won in value (as assessed by the government) at the time of sale.

18. According to simulations by the Korean authorities, the lock-in effect seems to be negligible in Korea. Less than half of multiple homeowners, around 3 4\% of the total 9.7 million households, are subject to the $50 \sim 60 \%$ rate on capital gains. As for single homeowners, around $91 \%$ of total households, most are exempted, and only $2 \sim 3 \%$ pay capital gains tax at an effective rate of $5 \sim 6 \%$ on average. 


\section{Summary of government housing policies}

28. The Korean situation is sometimes compared with Japan's "bubble economy" of the late 1980s. The severe aftermath of the bubble, which resulted in a crisis in the financial system and a decade of economic stagnation, has been used as a rationale for policies to control the housing market. However, the situation of Japan during the bubble period was substantially different from the present situation in Korea (Box 2). Moreover, the interventionist approach taken in Japan was ineffective and, in the end, counterproductive and these policies have been largely abandoned in recent years.

29. In practice, it is difficult or impossible to distinguish price hikes due to real demand from those caused by speculation. Even if property price increases in urban centres may sometimes result in overvaluation and a possible spill-over to other areas, the authorities should be extremely cautious in trying to curb such increases, as there is a high degree of uncertainty about the impact of pre-emptive policies and the length of time for such policies to take effect. In the case of the United States, for example, the government decision not to intervene in the housing market appears to have been correct despite the large price hikes in some areas that were unsustainable. Moreover, house price hikes have the positive impact of increasing the resilience of an economy through wealth effects, especially in the case of Korea, where domestic demand is currently relatively sluggish. ${ }^{19}$ There is little sign of macroeconomic overheating, while the series of real estate stabilisation measures since 2005 have tended to have a negative impact on economic activity by reducing construction activity (see the 2007 OECD Economic Survey of Korea).

30. Policies to discourage speculation tend to exacerbate price volatility, as noted above, in part by raising expectations of future policy changes. For example, a poll conducted right after the announcement of the August 2005 policy package showed that $65 \%$ predicted housing price increases over the following six months to one year. Government policies should instead focus on maintaining sound macroeconomic management and creating an efficient housing market rather than on measures to control short-run house price fluctuations.

\section{Box 2. Japan's experience with a real estate price bubble}

The property price bubble started in the Tokyo region, where the average price for residential land rose by over $50 \%$ in 1987 and then spread across the rest of the country. By 1991, the average nation-wide residential land price was $46 \%$ above its 1986 level and $120 \%$ higher in Tokyo. Even excluding the three largest metropolitan regions, residential land prices increased by a quarter over that period. In contrast, inflation, as measured by the consumer price index, remained steady at around $2-3 \%$ per year. A wide range of policies introduced by the government to control real estate prices, such as limiting the volume of land transactions and introducing the Land Value Tax on large landowners, proved ineffective or even counterproductive. The government even introduced a plan to build a new city to relocate central government functions outside of Tokyo. In sum, while the magnitude of real estate price hikes in Korea is only a fraction of that in Japan during the 1980s, the Korean authorities are pursuing policies that are more interventionist than those taken by the Japanese government - policies that in the end proved to be ineffective and counterproductive.

In Japan, nation-wide land prices started to fall rather abruptly in 1992, followed by 14 consecutive years of decline. The collapse of the bubble, which sharply boosted the non-performing assets held by banks, was a major cause of the decade of economic stagnation. The seriousness of the situation finally pushed the government to make a drastic reform of its urban and regional policy. First, building and zoning regulations in the centre of large cities were relaxed dramatically. The government allowed private developers to ignore existing zoning codes in the centre of major cities, which were designated as "Urgent Urban Revitalisation Areas". Building codes were also relaxed substantially, and the introduction of the transaction system for space rights encouraged large-scale redevelopment projects in city centres. Second, laws that had restricted the building of factories and universities in the Tokyo and Osaka regions since the 1960s were abolished. Third, public investment, which was heavily used to support regional economies during the 1990s, has been cut by almost half as a share of GDP in ten years, while some progress was made in

19. Real estate accounts for about $85 \%$ of household wealth in Korea. 
shifting financial resources to key infrastructure projects in large cities. Fourth, the Housing Loan Corporation, which had dominated the mortgage market thanks to large government subsidies, was re-organised into a new administrative agency mainly responsible for the securitisation of housing loans in April 2007, with the aim of limiting the role of the public sector. In addition, the role of public corporations in charge of housing construction and urban development has been focused on supporting the private sector, following a hike in their debt and non-performing assets. Fifth, the plan to build a new city to relocate government functions was frozen.

Land prices finally stabilised and started to rise in the centre of large cities in the early 2000 s, and the average land prices in the three largest cities increased in 2006 for the first time in 16 years. Residential land prices in central Tokyo are now growing at an annual rate of more than $20 \%$. However, no policies to contain such price increases have been implemented or seriously considered thus far. On the other hand, land prices in regional cities continue to drop as migration into the Tokyo region, which was stagnant in the mid-1990s, has picked up again in recent years.

\section{Policies to achieve balanced regional development}

31. Achieving balanced regional development by limiting the concentration of population and economic activity in the capital region has been a priority of the Korean government for the past several decades. This priority is strongly linked to the housing issue as it is expected to reduce demand for real estate in the capital region. This section looks at the degree of concentration in the capital region and examines the effectiveness of government policies to achieve balanced regional development.

\section{The degree of concentration in the capital region and its impact}

32. Concentration in the capital region - Seoul, Incheon and Gyeonggi Province - is indeed high. With $12 \%$ of Korea's area and a population of 23.5 million, it is the second largest agglomeration in the OECD area after the Tokyo region, and accounts for $48 \%$ of Korea's population. Agglomeration economies attract firms to metropolitan areas by offering a wide range of specialised business services and high quality infrastructure. ${ }^{20}$ Hence, large agglomerations are often a source of aggregate growth, boosting output and productivity. However, Korea is an exception (OECD, 2006a) as per capita income and labour productivity in the capital region are on par with the national average, according to Korean statistics. Compared to other OECD countries, Korea has a relatively modest level of regional variation in per capita income (OECD, 2005c). Moreover, economic growth in the capital region between 1995 and 2002 lagged behind the national average. Although there is a possible downward bias due to statistical problems in calculating regional GDP (Kook, 2005), there appear to be important diseconomies of agglomeration in the Seoul region that reduce income and growth (OECD, 2006a) ${ }^{21}$

33. Traffic congestion has continued to worsen in the capital region. It is estimated that Korea lost about 3.0\% of its GDP in 2004 due to congestion, according to the MCT. In addition to increased economic activity in Seoul, growing suburbanisation has led to explosive growth in commuting between Seoul and the rest of the capital region. The share of public transport use remained at $63 \%$ between 1999 and 2005 despite continued investment in subways and the introduction of bus-only lanes. The share of passenger cars increased from $20 \%$ to $26 \%$ over the same period, while the proportion of those vehicles with only one passenger increased from $69 \%$ to $78 \%$. More commuters choose to drive partly due to the lack of efficient public transport across the capital region (OECD, 2005d). Traffic congestion has exacerbated the severe pollution problem around Seoul (see Box 3).

20. Agglomeration economies are confirmed by the positive correlation between city size and income, especially cities accounting for over $20 \%$ of GDP (OECD, 2006a). Capital cities are at the forefront.

21. Henderson (2000) found Korea to be among the countries with a highly excessive concentration in the largest city based on an econometric analysis using data between 1960 and 1995. 


\section{Box 3. Addressing air pollution in the capital region}

Korea has achieved significant success in addressing the problem of air pollution. ${ }^{*}$ While economic output rose $27 \%$ between 1997 and 2003, emissions of SOx were reduced by $36 \%$ and those of NOx, VOCs and total suspended particulate matter (TSP) were held to moderate increases. Indeed, emissions per unit of GDP are half the OECD average for SOx and close to the average for NOx (Figure 10). However, several challenges remain. The concentration of $\mathrm{NO} 2$ and particulates in the capital region is still higher than in many other large cities, reflecting the rapid rise in car use, which has outpaced improvements in fuel quality and engine technology. In addition, the concentration of PM10 in Seoul was about twice as high as that in New York, London and Tokyo.

Korea has strengthened its air quality policy since the early 2000s in response to health and quality of life concerns. Its ambient air quality standards were upgraded in 2006 and, with some exceptions, are now close to WHO guidelines. A comprehensive ten-year air quality plan for the Seoul metropolitan area, announced in 2005, targets a $41 \%$ to $47 \%$ reduction in pollutant emission by 2014 by introducing comprehensive market-based and flexible measures.

First, for stationary sources, the cut in emissions is to be achieved through a total pollution load management and emission trading ("cap and trade") system. It will take effect in July 2007 in the capital region for SOx, NOx and TSP. It will be applied initially to large sources and extended to mid-sized sources in 2009. The emission levels of SO2, NOx and TSP will be allocated to each source within the overall total limit set for the metropolitan area. Emitters with excess pollution will then be able to purchase emission permits from those with surplus emission allowances. In case emitters exceed their allocated amount, they have to pay a penalty charge and their permissible emission level is reduced for the following year.

Second, a wide range of measures are being implemented to reduce emissions and energy consumption by onroad mobile sources, which are the major emission sources in the Seoul metropolitan area $(51 \%$ of NOx and $65 \%$ of PM10 emissions). Vehicles must comply with the most stringent international emission standards. For diesel vehicles, Euro 3 emission standards have been in force since 2002 for light-duty vehicles. Euro 4 emission standards were introduced in 2006 for passenger vehicles and heavy-duty vehicles, and are to be introduced in 2007 for light-duty vehicles. For gasoline vehicles, the US federal LEV (Low Emission Vehicles) standards were introduced in 2003 and the ULEV (Ultra-Low Emission Vehicles) standards in 2006. Vehicle emission inspection has also been strengthened. An emission inspection was added to the general inspection in 2002, which must be carried out every two years for non-commercial passenger vehicles and annually for heavy-duty vehicles for commercial use. In particular, diesel vehicles that exceed emission standards must be equipped with an emission reduction device or retrofitted with a LPG engine. Fuel standards have also been strengthened to the level of the EU standard. Other measures include the subsidised introduction of low-emission vehicles such as compressed natural gas (CNG) buses, mandatory public procurement of low-emission cars such as hybrids, increased production of low-emission vehicles by car manufacturers (from 1.5\% in 2006 to $6.6 \%$ in 2010) and restrictions on the use of construction materials emitting excessive harmful substances.

Third, the Korean government has introduced measures to reduce energy intensity, which is $21 \%$ above the OECD average. High energy intensity reflects distortions created by past energy pricing policies that aimed at economic growth and price stabilisation, without regard to air pollution, energy efficiency and climate concerns. The aim is to achieve a more appropriate ratio of relative prices among petrol, diesel and liquefied petroleum gas (LPG) through fuel taxes. In 2002, this ratio was set at 100: 75: 60. It was changed to 100: 85: 50 in 2005, taking into account environmental concerns related to diesel.

With comprehensive measures in place to tackle air pollution issues in the Seoul metropolitan area, there is a growing need to implement similar plans for other major cities and industrial complexes. Moreover, Korea should introduce additional economic instruments in implementing its air management policy, such as internalising the external costs of transport while ensuring that the marginal benefits of new policies exceed the costs. Finally, the use of renewable energy sources, which account for just $2.1 \%$ of total energy supply, should be expanded.

*This box draws on the OECD Environmental Performance Reviews: Korea (2006c) and information from the Ministry of the Environment in Korea. 
Figure 10. Air pollutant emissions
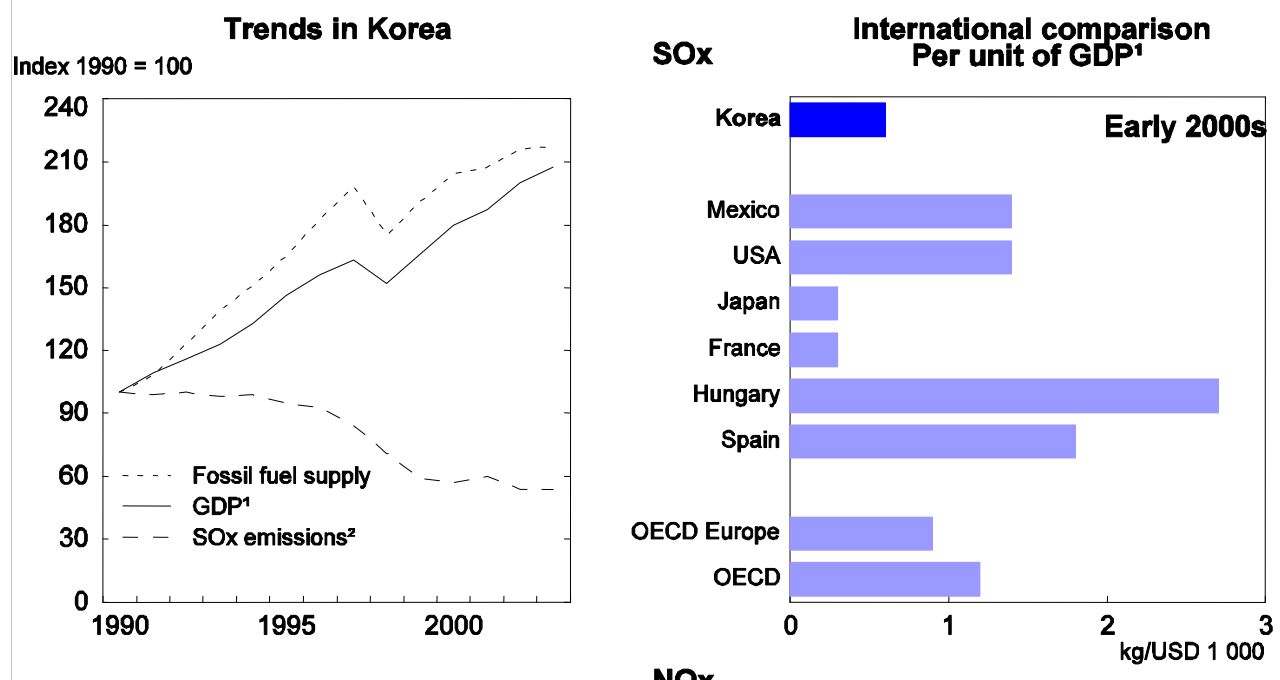

Index $1990=100$
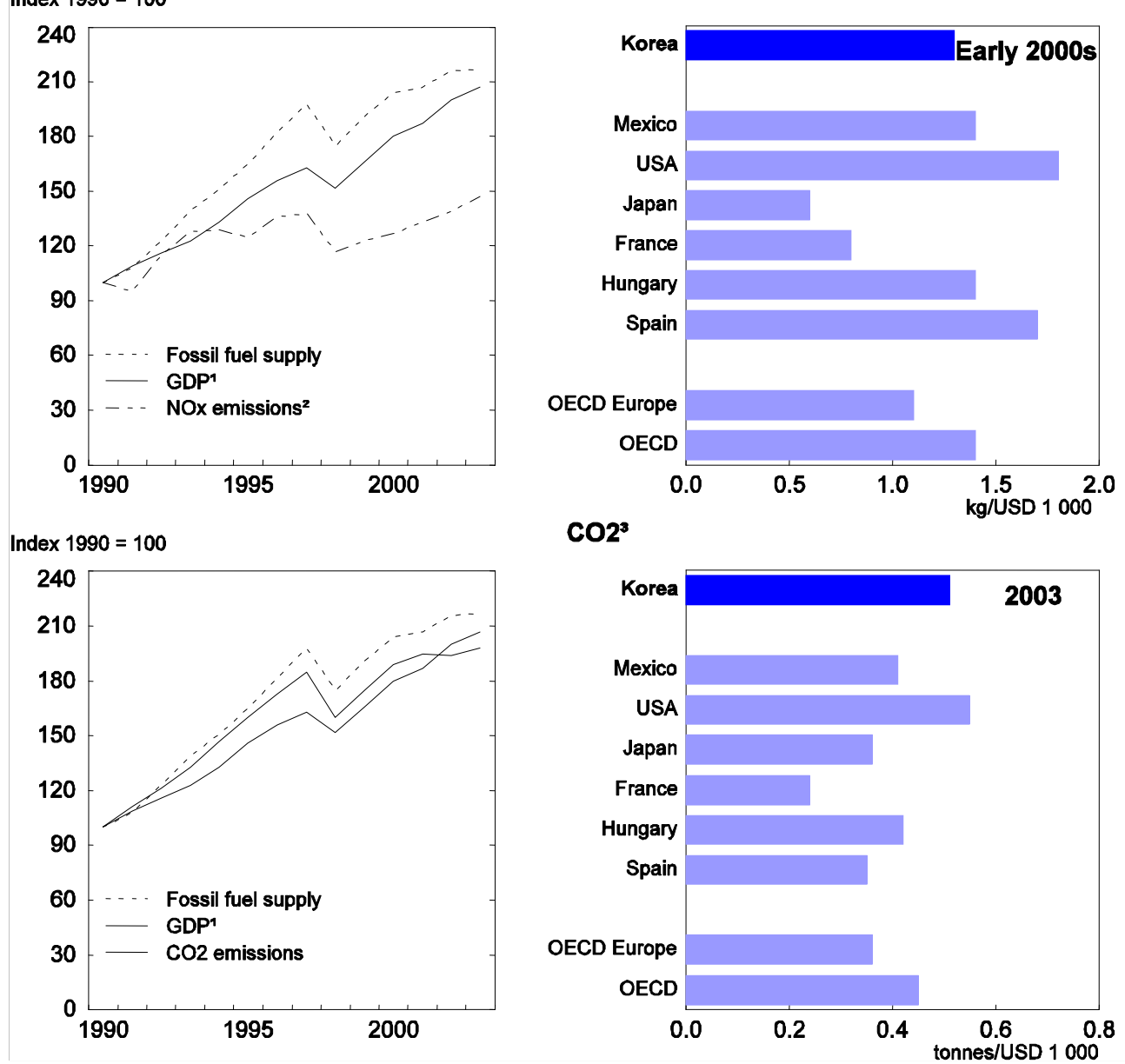

1. GDP at 2000 prices and purchasing power parity exchange rate.

2. 1990-1998: Secretariat estimates.

3. Emissions from energy use only; sectoral approach; excludes international marine and aviation bunkers.

Source: OECD Environment Directorate; OECD-IEA (2005), CO2 emissions from fuel combustion; OECD (2005), OECD Economic Outlook, No.77; OECD-IEA (2005), Energy balances of OECD countries 2002-2003, OECD,

Paris; and OECD (2006), OECD Environmental Performance Reviews: Korea, OECD, Paris. 


\section{Policies to limit concentration in the capital region}

34. The negative externalities resulting from the high degree of concentration in the capital region provide a rationale for policies to disperse economic activities to other parts of the country. Special measures were introduced as early as the 1960s, including the relocation of certain government institutions and university branches and the provision of financial incentives to move firms out of the capital region. Construction of large-scale facilities in the capital region, including factories, universities, and other facilities that induce population concentration, are still prohibited or controlled by the government (OECD, 2001 and OECD, 2005d). However, the effectiveness is reduced by a number of exceptions that have been introduced, such as for small and medium-sized enterprises (SMEs), venture businesses, foreign-invested companies and advanced-technology firms. The government plans to replace direct regulations by economic instruments, possibly during the early 2010s, in tandem with progress in achieving balanced regional development through the various regional development initiatives discussed below.

35. However, the current strategies have a number of weaknesses. First, there is limited evidence that capital region regulations have actually promoted growth in other regions. Despite the restrictions, the capital region's share of Korea's population has risen from 18\% in the 1980 s to nearly half. Experiences in other OECD countries, such as France, Japan and the United Kingdom, demonstrate that regulatory policies to control the growth of capital regions have not been effective. ${ }^{22}$ Second, there is concern that anti-concentration policies are holding back Seoul's international competitiveness. In an increasingly globalised economy, firms that cannot find suitable sites in the capital region may invest instead in other countries. ${ }^{23}$

36. Addressing negative externalities by imposing restrictions on the location of certain economic activities is a costly approach. Enterprises that would benefit the most from locating in the capital region are often excluded, while the possibility of obtaining exceptions to restrictions prompts lobbying. Instead, negative externalities related to high levels of concentration can be better addressed by economic instruments. The introduction of a cap and trade system for pollutant emissions is a step in the right direction (Box 3). Given that a large part of negative externalities, such as congestion and air pollution, is related to the transport system, one approach would be to introduce congestion charges, an approach that has been implemented in some major cities in the OECD area. A peak-load pricing system on roads and trains would reduce congestion at peak times while encouraging businesses with heavy traffic loads to move out of the congested area. Meanwhile, public transport in Seoul could be improved further by changing the regional allocation of public investment in favour of the capital region.

22. There is little reliable data showing whether constraints imposed on the growth in the major regions in some OECD countries were effective in encouraging economic activities in other regions, thus compensating the loss in the major regions with higher growth elsewhere in the country. In the United Kingdom, both deterrents and incentives were used to limit the high concentration in London from the 1960s to 1970s, but the rate of office floorspace development in London accelerated in the next decade. In France, the decision to relocate some public research centres outside the Paris metropolitan area led to a deterioration in its performance in innovation capacity and competitiveness compared to other EU countries (OECD, 2005d and 2006a). Japan's experience is discussed in Box 2.

23. The recent case of Hynix, which was denied permission to build a plant in the capital region, prompted a debate on this issue. 


\section{Policies to achieve "balanced regional development"}

37. Policies to limit population and economic activities in the capital region are accompanied by measures to promote development in other parts of the country. A special law for balanced national development was enacted in 2004, with a special account of 5.5 trillion won ( $0.7 \%$ of GDP) to support the initiative. The special account is to be increased to 7.5 trillion won in 2009. Initiatives to promote balanced development include the building of a new administrative city and the creation of "innovation cities" and "enterprise cities". In February 2007, the government announced that it would consider providing stronger tax incentives, including a permanent reduction of the corporate tax burden for companies that move their headquarters from the capital region to other parts of the country. In addition, special zones (see the 2007 OECD Economic Survey of Korea) may affect regional development.

38. At the centre of the government's balanced national development strategy is the creation of a new administrative city in Chungcheong Province, located 150 kilometres south of Seoul. Construction is due to begin in July 2007 and the relocation of 49 central government agencies, including 12 ministries, is scheduled to occur between 2012 and 2014. The target population of the city is 500000 in 2030.

39. The innovation cities initiative aims at strengthening the link between public organisations, industry and universities through the relocation of public organisations, thereby creating a favourable environment for private investment and innovation. The designated areas are classified as industrial, knowledge-based, tourism and leisure or innovation-based areas. The innovation cities will benefit from the transfer of 175 public institutions from the capital region, thus reducing the share of public organisations located in the capital region from $85 \%$ to $35 \%$. Local governments are required to provide high quality urban infrastructure in these areas. The enterprise cities offer incentives similar to those in the Free Economic Zones (see Jones and Yoon, 2008), such as simplified planning procedures and exemptions and reductions from national and local taxes on firms in order to encourage private firms to take the lead in development. Companies are also allowed to set up schools and hospitals in these areas. The six areas designated thus far are relatively small regional cities outside of large metropolitan areas.

40. Although most OECD countries implement some kinds of regional policies, the extensive programmes in Korea are ambitious and aim at a high level of regional redistribution compared with other countries. In recent years, a number of OECD countries have shifted away from policies aimed at greater equality across regions, giving more autonomy to sub-national governments in implementing strategies for local development (Morasch, 2000 and OECD, 2005a). This shift reflects the fact that policies that attempted to influence industrial location through subsidies and incentives have proven to be ineffective or too costly. Indeed, the tax reduction for companies moving outside of Seoul could significantly reduce tax revenues, given that firms headquartered in Seoul paid 20 trillion won (2.5\% of GDP) of corporate taxes in 2004. In addition, overlapping programmes administered by various government agencies often result in the waste of resources and inefficiency. Furthermore, since preferential regulatory measures applied in geographically limited areas distort the location of businesses, the first best approach is to implement them on a nation-wide basis. In sum, the Korean government's regional policy should not focus on changing the regional distribution of population and economic activities per se, but should instead increase local autonomy in implementing regional development policy. Meanwhile, central government initiatives should be streamlined to improve their efficiency. 


\section{Fiscal decentralisation}

41. Fiscal decentralisation is essential to make local governments more accountable for their policies and enhance the quality of public services in line with the demands of citizens. The 2005 OECD Economic Survey of Korea pointed out a number of problems with the relationship between levels of governments:

- The historical legacy of centralised control has left excessive authority at the central level. In addition, weak self-governance and a lack of capability in local governments have restricted the effective use of the power that they have.

- Local governments have limited spending responsibilities. In particular, the education budget is largely outside the control of the local authorities.

- The severe imbalance in the financial resources of central and local governments requires most local authorities to rely on transfers from the central government. While own-source revenues account for $95 \%$ of total revenue in Seoul, a high level by international standards, $84 \%$ of local governments rely on central government transfers for more than one-half of their revenues.

- The heavy reliance on earmarked grants, and the conditions attached to such grants, further reduce the autonomy of local governments.

Although the Roadmap for Fiscal Decentralisation in 2003 placed this issue near the top of the policy agenda, there has been little progress to date.

42. The issue of housing policy as discussed above is linked to fiscal decentralisation as propertyrelated taxes account for almost half of local government tax revenue. Simplifying the local tax system, by eliminating some of the 16 local taxes, as recommended in the 2005 OECD Economic Survey of Korea, would further increase local government dependence on property taxes. The lack of spending responsibilities for local governments limits their need for additional revenue. Indeed, some wealthy jurisdictions in the capital region lowered property tax rates in response to rising revenue as tax bases increased, thus frustrating the government's plan to raise the effective rate on property holding. It is thus important to give more spending responsibility to local governments, while encouraging them to make use of their existing flexibility in setting tax rates. Moreover, it should be clear that changes in tax rates will not influence the level of transfers from the central government.

43. There is a concern that increased autonomy would result in greater disparity in regional income. Although some studies have found that fiscal decentralisation helps to narrow regional income disparity (Canaleta et. al., 2004), the wide variation in the financial capacity between regions in Korea suggests that fiscal decentralisation would have a negative impact on regional equity. As pointed out in the 2005 Economic Survey of Korea, the main challenge is to provide local governments with sufficient revenueraising autonomy while ensuring adequate revenue capacity through a well-designed system of block grants. However, the success of such a strategy of increased autonomy depends on granting more spending responsibility for local governments.

\section{Conclusion}

44. The attention focused on housing policies, as illustrated by the five packages introduced during the past 18 months, appears incommensurate with the relatively modest increases in housing prices from an international perspective. House prices, however, have become a very sensitive political issue because of a more rapid pace of increase in the price of apartments in the capital region. A main reason is the decline in private supply of housing caused by difficulties in securing construction sites, in part due to persistent 
regulations, while demand for housing has increased due to favourable living conditions in this area, including the availability of high quality education. The government fears that the large price rises in the capital region could spill over to other parts of the country and it is also concerned about the large capital gains for some people and a widening dispersion of wealth. It is for these reasons that the government has responded to wide-spread public concern regarding house price rises by acting on a variety of fronts. The government measures have to be seen in the context of its objective of limiting large house price swings in the short term. Despite the merits of such a policy objective, some of these policies have the potential to create substantial harm if allowed to persist in the long-term. The government should, therefore, aim to establish an efficient housing market in which supply responds to price signals. Efforts to restrict demand for housing or engineer price declines, particularly though measures that are inconsistent with market principles, need to be phased out, as regulatory changes on land use are implemented and housing supply becomes more elastic. A less interventionist approach may also reduce price volatility, reducing the scope for capital gains, and would also increase the resilience of the overall economy.

45. The government's decision to boost the supply of housing in the capital region is appropriate. Meanwhile, it is important to avoid costly and inefficient measures aimed at changing the distribution of population and economic activity, while granting more autonomy to local governments in promoting economic development as part of fiscal decentralisation. Specific recommendations to improve housing and regional policies are shown in Box 4.

\section{Box 4. Summary of recommendations for housing and regional policies in Korea}

\section{Housing policy}

- Phase out policies aiming at controlling short-term price fluctuations, such as price caps and the requirement to disclose construction costs, particularly in geographically limited areas, and instead focus on creating a robust housing market from a long-term perspective, as regulatory changes on land use are implemented and housing supply becomes more elastic.

- Maintain the focus on increasing the supply of housing, particularly in the capital region.

- Concentrate the role of the public sector on developing more land for housing construction, while reducing regulations on construction and land use to facilitate a stronger private-sector response to demand.

- Make more publicly developed land available for private-sector housing projects to better match consumers' preferences.

- Phase out restrictions on the reconstruction of apartments, particularly in areas where prices are rising.

- Relax regulations on mortgage lending by the private sector without undermining strong prudential supervision of financial institutions.

- Encourage the development of the private-sector mortgage market, in part by developing the long-term bond market.

- Continue to lower property transaction taxes and increase property holding taxes, while not relying on property taxes as a tool to control property prices or redistribute income.

- $\quad$ Avoid high capital gains tax rates to limit the extent of distortions. 
ECO/WKP(2008)21

\section{Regional policy and fiscal decentralisation}

- Transform regulations that limit construction in the capital region into market-based instruments aimed at addressing externalities, such as pollution and congestion.

- $\quad$ Streamline various initiatives aiming at balanced regional development and give local government more autonomy to develop regional development programmes, while expanding nation-wide the preferential treatment granted in "enterprise cities".

- $\quad$ Further pursue fiscal decentralisation by granting greater autonomy to local governments, including more responsibility for providing services such as education and police. 
ECO/WKP(2008)21

\section{BIBLIOGRAPHY}

Catte, P., N. Girouard, R. Price and C. Andre (2004), "Housing markets, wealth and the business cycle", OECD Economics Department Working Paper No. 394, OECD, Paris.

Canaleta, C. G., P. P. Arzoz and M. R. Garate (2004), "Regional Economic Disparities and Decentralisation", Urban Studies, Vol. 41.

Cho, Dongchul (2005), "Interest rate, inflation, and housing price: with an emphasis on Chonsei price in Korea", NBER Working Paper 11054, National Bureau of Economic Research.

Council of Local Authorities for International Relations (2006), "Balanced national development policies in Korea", CLAIR Report No. 289 (in Japanese).

Girouard, N., M. Kennedy, P. van den Noord and C. Andre (2006), "Recent house price developments: the role of fundamentals", OECD Economics Department Working Paper No. 475, OECD, Paris.

Glaeser, E. L., J. Gyourko and R. E. Saks (2005), “Urban Growth and Housing Supply”, NBER Working Paper 11097, National Bureau of Economic Research.

Hannah, L., Kyung-Hwan Kim and E. S. Mills (1993), "Land Use Controls and Housing Prices in Korea", Urban Studies, Vol. 30, No. 1.

Helbling, T. F. (2005), "Housing price bubbles - a tale based on housing price booms and busts", BIS Paper No. 21, Bank for International Settlements, Basel.

Henderson, V. (2000), "How Urban Concentration Affects Economic Growth", Policy Research Working Paper 2326, the World Bank, Washington, D.C..

Henderson, V., T. Lee amd Yung Joon Lee (2001), "Scale Externalities in Korea", Journal of Urban Economics, Vol. 49.

Himmelberg, C., C. Mayer and T. Sinai (2005), "Assessing High House Prices: Bubbles, Fundamentals, and Misperceptions", Staff Report No. 218, Federal Reserve Bank of New York.

Jones, Randall S. and Taesik Yoon (2008), "Enhancing the Globalisation of Korea", OECD Economics Department Working Paper, forthcoming, OECD, Paris.

Jones, Randall S. and Tadashi Yokoyama (2005), "Getting the most out of public-sector decentralisation in Korea”, OECD Economics Department Working Paper No. 468, OECD, Paris.

Kim, Jin Yoo and Chang-Moo Lee (2004), "Impact of Change of Urban Structure on Housing Price Dynamics: Application of a Modified Repeat Sales Model", AsRES 2004 Conference Papers, The Asian Real Estate Society.

Kim, Kyung-Hwan (2004), "Housing and the Korean economy”, Journal of Housing Economics, Elsevier. 
Kim, Kyung-Hwan (2006), "Economics of Real Estate Markets and Government Policies", Lecture for the Graduate School of International Studies, Ewha Womans University, Seoul.

Kim, Kyung-Hwan and S. M. Wachter (2006), "Housing and Government Policy in the Global Economy: The Cases of Korea and the US", mimeo, Sogang University.

Kook, Joong-Ho (2005), "Regional Disparities As Seen From Major Statistics: A Comparison Between Japan and the ROK", ERINA Discussion Paper No. 0503, Economic Research Institute for Northeast Asia (in Japanese with English summary)

Kookmin Bank, National Housing Price Survey, monthly publication.

Le Bas C. and F. Miribel (2005), "The agglomeration with information technology activities: an empirical study of the US economy", Industrial and Corporate Change, Vol. 14, No. 2.

Lee, Bun Song, Sosing Kim and Sung Hyo Hong (2005), "Sectoral Manufacturing Productivity Growth in Korean Regions", Urban Studies, Vol. 42, No. 7.

Morasch, K. (2000), Decentralization of Industrial Policy as Strategic Delegation, Beitrag 193, Volkswirtschaftliche Diskussionsreihe, Universitaet Augsburg.

OECD (2001), OECD Territorial Review of Korea, OECD, Paris.

OECD (2005a), Building Competitive Regions: Strategies and Governance, OECD, Paris.

OECD (2005b), OECD Economic Survey of Korea, OECD, Paris.

OECD (2005c), OECD Regions at a Glance, OECD, Paris.

OECD (2005d), OECD Territorial Review of Seoul, Korea, OECD, Paris.

OECD (2006a), Competitive Cities in the Global Economy, OECD Territorial Reviews, Paris.

OECD (2006b), "Has the rise in debt made households more vulnerable?"OECD Economic Outlook No. 80, OECD, Paris.

OECD (2006c), OECD Environmental Performance Reviews: Korea, OECD, Paris.

OECD (2007), OECD Economic Survey of Korea, OECD, Paris.

Oxley, M. (2004), Economics, Planning and Housing, Palgrave Macmillan. 
ECO/WKP(2008)21

\section{Annex 1}

\section{Key elements of the policy packages for property price stabilisation since 2005}

\section{August 2005 package}

1. Expand the National Housing Fund from 1.5 trillion won to 2 trillion won in order to assist low and middleincome people to purchase homes.

2. Expand public rental housing construction by allowing the construction of additional National Rental Housing Complexes and boosting government support for rental housing from 11.4 trillion won to 13.1 trillion won.

3. Revitalise the supply of private rental housing through regulatory incentives, while expanding tax benefits for private rental housing businesses.

4. Enhance transparency in property transactions by requiring that actual prices be reported to local governments and by establishing a surveillance system targeting speculators likely to disturb the market.

5. Strengthen the Comprehensive Property Tax and raise the capital gains tax to curb speculative demand.

6. Boost housing supply in the capital region by providing extra public land, and provide incentives to encourage redevelopment led by public companies.

\section{March 2006 package}

1. Enhance the welfare of low and middle-income people by:

- $\quad$ Strengthening financial support for rental housing for low income and precarious households.

- $\quad$ Cutting apartment prices by relaxing zoning regulations and expanding public rental housing.

2. Rationalise the redevelopment system by increasing the transparency of the construction process and taxing windfall redevelopment gains up to $50 \%$.

3. Achieve a sustainable expansion of housing supply of more than 0.3 million housing units per year on average until 2010 by providing additional public housing sites in the capital region and using fiscal expenditures and regulatory incentives to encourage the development of existing urban areas.

4. Require purchasers of homes in certain areas to report to local governments how they will finance the purchase of the home and whether they will live in the home.

5. Disperse housing demand by promoting balanced regional development throughout the country by creating innovation cities and enterprise cities and encouraging the development of lagging regions in urban areas.

\section{November 2006 package}

1. Increase the housing supply by front-loading the plan to provide land for housing construction and relaxing regulations, such as the mandatory greenfield ratio.

2. Reduce the prices of new apartments in new towns by $25 \%$ by:

- Relaxing the floor space-to-land ratio ( $8 \%$ reduction in price).

- Changing the land price calculation method to lower its price (10\% reduction in price).

- Shortening the housing construction period ( $6 \%$ reduction in price). 
3. Tighten restrictions on home-backed loans from financial institutions for houses with a market value of more than 600 million won.

- Terminate the exceptional treatment that allows loan-to-value (LTV) ratios of up to $60 \%$ for banks and insurance companies. The ratio should be a maximum of $40 \%$.

- Lower the maximum LTV ratio to $50 \%$ for non-bank financial institutions.

- Expand the coverage of the debt-to-interest (DTI) ratio restriction of $40 \%$ to nearly the entire capital region.

4. Increase access to housing for low-income households by further expanding financial support from the National Housing Fund and the Korea Housing Finance Corporation.

5. Build 1.64 million housing units by 2010 while expanding the role of the public sector $(0.87$ million units on public land and 0.77 million units on privately-owned land).

\section{January 2007 package}

1. Require private-sector builders to publicly disclose their construction costs for housing projects in the capital region and designated "overheating" zones in other areas from September 2007 (such a requirement is already applied to government-run housing projects).

2. Set a price ceiling on new homes nation-wide. It is to be based on the construction costs, assessed land prices and what the local government regards as a proper level of profit.

3. Limit mortgage loans in speculation zones to only one per person.

4. Ban the re-sale of all new houses in the capital region for five to seven years, depending on the size of the house.

5. Favour households with no home and at least two children and the elderly in the subscription for new houses, while penalising multiple home owners.

\section{January 2007 package}

1. Increase the stock of long-term rental housing by 2.6 million (from 0.8 million in 2006 to 3.4 million in 2017), raising the share of rental housing in total housing from $6 \%$ to $20 \%$ over that period.

2. Create a rental housing fund, amounting to 90 trillion won (10\% of GDP) by 2019 (yearly average of 7 trillion won between 2007 and 2019) to construct 0.5 million rental housing units.

- Attract investors from the public sector, such as the National Pension Fund, agricultural co-operatives, Postal Savings, and the private sector, by offering a guaranteed rate of return slightly above the government bond rate.

- Provide government subsidies of 0.5 trillion won each year between 2008 and 2019 for the construction of rental housing by public-sector developers, such as the Korea Land Corporation and Korea National Housing Corporation. 


\section{WORKING PAPERS}

The full series of Economics Department Working Papers can be consulted at www.oecd.org/eco/Working_Papers/

612. Moving towards more sustainable healthcare financing in Germany

(May 2008 N. Brandt

611. Improving education outcomes in Germany

(May 2008) David Carey

610. Have developed countries escaped the curse of distance?

(May 2008) Hervé Boulhol and Alain de Serres

609. Measures of international transport cost for OECD countries $\backslash$

(April 2008) Stephen S. Golub and Brian Tomasik

608. Encouraging labour force participation in Chile

(April 2008) D. Contreras, L. de Mello and E. Puentes

607. Tackling business and labour informality in Chile

(April 2008) D. Contreras, L. de Mello and E. Puentes

606. Delivery cost-efficient public services in health care, education and housing in Chile (April 2008) D. Contreras, L. de Mello and E. Puentes

605. Managing Chile's macroeconomy during and after the copper price boom (April 2008) Luiz de Mello

604. Avoiding the value added tax: Theory and cross-country evidence (April 2008) Luiz de Mello

603. Oil Price Shocks, Rigidities and the Conduct of Monetary Policy: Some Lessons from a New Keynesian Perspective

(April 2008) Romain Duval and Lukas Vogel

602. The Contribution of Economic Geography to GDP Per Capita (April 2008) Hervé Boulhol, Alain de Serres and Margit Molnar

601. Estimating a supply block for Poland

(April 2008) Rafal Kierzenkowski, Patric Ollivaud, Franck Sédillot and Philippe Briard

600. Product market regulation and economic performance across Indian states

(March 2008) Paul Conway, Richard Herd and Thomas Chalaux

599. Improving product market regulation in India: an international and cross-state comparison (March 2008) Paul Conway and Richard Herd

598. Revenue buoyancy and its fiscal policy implications (February 2008) Isabelle Joumard and Christophe André 
597. Monetary policy, market excesses and financial turmoil (February 2008) Rudiger Ahrend, Boris Cournède and Robert Price

596. Explaining differences in hours worked among OECD countries: an empirical analysis (February 2008) Sven Blondal and Jean-Marc Burniaux

595. Fiscal policy in India: past reforms and future challenges (February 2008) Richard Herd and Willi Leibfritz

594. The significance of Switzerland's enormous current-account surplus (March 2008) Peter Jarrett and Céline Letremy

593. Interdependencies between monetary policy and foreign-exchange intervention under inflation targeting: the case of Brazil and the Czech Republic

(January 2008) Jean-Yves Gnabo, Luiz de Mello and Diego Moccero

592. Solow or Lucas? Testing growth models using panel data from OECD countries (December 2007) Jens Arnold, Andrea Bassanini and Stefano Scarpetta

591. The private internal rates of return to tertiary education: new estimates for 21 OECD countries (December 2007) Romina Boarini and Hubert Strauss.

590. Making federalism work

(December 2007) Alexandra Bibbee

589. The wage premium on tertiary education: New estimates for 21 OECD countries (December 2007) Hubert Strauss and Christine de la Maisonneuve

588. Enhancing the benefits of financial liberalisation (March 2007) Stefan Ide, Jens Høj and Patrick Lenain

587. Improving incentives in tertiary education (March 2007) Jens Høj

586. Globalisation and the European Union: which countries are best placed to cope? (December 2007) David Rae and Marte Sollie

585. Primary and secondary education in the United States (November 2007) Peter Tulip and Gregory Wurzburg

584. Financing higher education in the United States (November 2007) Peter Tulip

583. Corporate net lending: a review of recent trends (November 2007) Christophe André, Stéphanie Guichard, Mike Kennedy and David Turner

581. Local government finances: The link between intergovernmental transfers and net worth (September 2007) Luiz de Mello

580. Boosting Austria's innovation performance improving innovation (September 2007) Willi Leibfritz and Jürgen Janger 